\title{
Article
}

\section{The Role of Acidity in the Synthesis of Novel Uranyl Selenate and Selenite Compounds and Their Structures}

\author{
Gabriel L. Murphy *(D), Philip Kegler (D), Eike M. Langer and Evgeny V. Alekseev* \\ Institute of Energy and Climate Research, Forschungszentrum Jülich GmbH, 52428 Jülich, Germany; \\ p.kegler@fz-juelich.de (P.K.); e.langer@fz-juelich.de (E.M.L.) \\ * Correspondence: g.murphy@fz-juelich.de (G.L.M.); e.alekseev@fz-juelich.de (E.V.A.)
}

Citation: Murphy, G.L.; Kegler, P.; Langer, E.M.; Alekseev, E.V. The Role of Acidity in the Synthesis of Novel Uranyl Selenate and Selenite Compounds and Their Structures. Crystals 2021, 11, 965. https://doi. org/10.3390/cryst11080965

Academic Editor: Evgeny Nazarchuk

Received: 13 July 2021

Accepted: 13 August 2021

Published: 16 August 2021

Publisher's Note: MDPI stays neutral with regard to jurisdictional claims in published maps and institutional affiliations.

Copyright: (C) 2021 by the authors. Licensee MDPI, Basel, Switzerland. This article is an open access article distributed under the terms and conditions of the Creative Commons Attribution (CC BY) license (https:/ / creativecommons.org/licenses/by/ $4.0 /)$.

\begin{abstract}
Herein, the novel uranyl selenate and selenite compounds $\mathrm{Rb}_{2}\left[\left(\mathrm{UO}_{2}\right)_{2}\left(\mathrm{SeO}_{4}\right)_{3}\right]$, $\mathrm{Rb}_{2}\left[\left(\mathrm{UO}_{2}\right)_{3}\left(\mathrm{SeO}_{3}\right)_{2} \mathrm{O}_{2}\right], \mathrm{Rb}_{2}\left[\mathrm{UO}_{2}\left(\mathrm{SeO}_{4}\right)_{2}\left(\mathrm{H}_{2} \mathrm{O}\right)\right] \cdot 2 \mathrm{H}_{2} \mathrm{O}$, and $\left(\mathrm{UO}_{2}\right)_{2}\left(\mathrm{HSeO}_{3}\right)_{2}\left(\mathrm{H}_{2} \mathrm{SeO}_{3}\right)_{2} \mathrm{Se}_{2} \mathrm{O}_{5}$ have been synthesized using either slow evaporation or hydrothermal methods under acidic conditions and their structures were refined using single crystal X-ray diffraction. $\mathrm{Rb}_{2}\left[\left(\mathrm{UO}_{2}\right)_{2}\left(\mathrm{SeO}_{4}\right)_{3}\right]$ synthesized hydrothermally adopts a layered $2 \mathrm{D}$ tetragonal structure in space group $\mathrm{P}_{2} / \mathrm{ncm}$ with $a=9.8312(4) \AA, c=15.4924(9) \AA$, and $V=1497.38(15) \AA$, where it consists of $\mathrm{UO}_{7}$ polyhedra coordinated via $\mathrm{SeO}_{4}$ units to create units $\mathrm{UO}_{2}\left(\mathrm{SeO}_{4}\right)_{5}{ }^{8-}$ moieties which interlink to create layers in which $\mathrm{Rb}^{+}$cations reside in the interspace. $\mathrm{Rb}_{2}\left[\left(\mathrm{UO}_{2}\right)_{3}\left(\mathrm{SeO}_{3}\right)_{2} \mathrm{O}_{2}\right]$ synthesized hydrothermally adopts a layered 2D triclinic structure in space group $P \overline{1}$ with $a=7.0116(6) \AA, b=7.0646(6) \AA$, $c=8.1793(7) \AA, \alpha=103.318(7)^{\circ}, \beta=105.968(7)^{\circ}, \gamma=100.642(7)^{\circ}$ and $V=365.48(6) \AA^{3}$, where it consists of edge sharing $\mathrm{UO}_{7}, \mathrm{UO}_{8}$ and $\mathrm{SeO}_{3}$ polyhedra that form $\left[\left(\mathrm{UO}_{2}\right)_{3}\left(\mathrm{SeO}_{3}\right)_{2} \mathrm{O}_{2}\right]$ layers in which $\mathrm{Rb}^{+}$ cations are found in the interlayer space. $\mathrm{Rb}_{2}\left[\mathrm{UO}_{2}\left(\mathrm{SeO}_{4}\right)_{2}\left(\mathrm{H}_{2} \mathrm{O}\right)\right] \cdot 2 \mathrm{H}_{2} \mathrm{O}$ synthesized hydrothermally adopts a chain $1 \mathrm{D}$ orthorhombic structure in space group $P m n 2_{1}$ with $a=13.041$ (3) $\AA, b=8.579$ (2) $\AA$, $c=11.583(2) \AA$, and $V=1295.9(5) \AA^{3}$, consisting of $\mathrm{UO}_{7}$ polyhedra that corner share with one $\mathrm{H}_{2} \mathrm{O}$ and four $\mathrm{SeO}_{4}{ }^{2-}$ ligands, creating infinite chains. $\left(\mathrm{UO}_{2}\right)_{2}\left(\mathrm{HSeO}_{3}\right)_{2}\left(\mathrm{H}_{2} \mathrm{SeO}_{3}\right)_{2} \mathrm{Se}_{2} \mathrm{O}_{5}$ synthesized under slow evaporation conditions adopts a $0 \mathrm{D}$ orthorhombic structure in space group $\mathrm{Cmc} 2_{1}$ with $a=28.4752(12) \AA, b=6.3410(3) \AA, c=10.8575(6) \AA$, and $V=1960.45(16) \AA^{3}$, consisting of discrete rings of $\left[\left(\mathrm{UO}_{2}\right)_{2}\left(\mathrm{HSeO}_{3}\right)_{2}\left(\mathrm{H}_{2} \mathrm{SeO}_{3}\right)_{2} \mathrm{Se}_{2} \mathrm{O}_{5}\right]_{2} \cdot\left(\mathrm{UO}_{2}\right)_{2}\left(\mathrm{HSeO}_{3}\right)_{2}\left(\mathrm{H}_{2} \mathrm{SeO}_{3}\right)_{2} \mathrm{Se}_{2} \mathrm{O}_{5}$ is apparently only the second example of a uranyl diselenite compound to be reported. A combination of single crystal X-ray diffraction and bond valance sums calculations are used to characterise all samples obtained in this investigation. The structures uncovered in this investigation are discussed together with the broader family of uranyl selenates and selenites, particularly in the context of the role acidity plays during synthesis in coercing specific structure, functional group, and topology formations.
\end{abstract}

Keywords: uranium; selenate; selenite

\section{Introduction}

The acquisition of novel non-centrosymmetric (NCS) structural phases has formed a topical focus of inorganic chemical synthesis development due to their prominent application in a variety of non-linear optic (NLO) [1,2], piezoelectric [3], and ferroelectric [4] based materials. In the case of NLO materials, stereo active lone pair possessing cations $\mathrm{Se}^{4+}$ and $\mathrm{I}^{5+}$ are commonly utilized as their possession of periodic polarizable free lone pair electrons within NSC lattices allow materials with superior second harmonic generation (SHG) properties to be obtained. A growing theme among recent NLO and SHG Se and I related material development studies has been the extension of these to uranium and actinide compounds, as it has been shown that their related properties can often exceed those of non-actinide variants [5-8]. The properties of these materials can be further improved through the increased polymerization of $\mathrm{IO}_{3}{ }^{-}$and $\mathrm{SeO}_{3}{ }^{2-}$ units into polyiodate and polyselenite units $[9,10]$. However, although often similarly chemically regarded due 
to their comparable ionic radii as oxoanions $\left(\mathrm{IO}_{3}{ }^{-}\right.$and $\left.\mathrm{SeO}_{3}{ }^{2-}\right)$, the dissimilar chemistry of the chalcogen group belonging Se cation to that of the Halogen I cation results in somewhat of a disparity in chemical insight, particularly regarding polymerisation of groups as oxoanions. For instance, at present a larger proportion of polyiodate units have been observed in the case of $\mathrm{I}_{2} \mathrm{O}_{5}, \mathrm{I}_{3} \mathrm{O}_{8}{ }^{-}, \mathrm{I}_{4} \mathrm{O}_{11}{ }^{2-}$, and $\mathrm{I}_{5} \mathrm{O}_{14}{ }^{3-}$ whereas only $\mathrm{Se}_{2} \mathrm{O}_{5}{ }^{2-}$ is reported for polyselenites [11-13]. Accordingly, understanding the synthesis conditions and design which pertain to the polymerization of $\mathrm{SeO}_{3}{ }^{2-}$ units is a pertinent pursuit in the context of next generation NLO and SHG material generation in addition to fundamental inorganic synthesis development.

It was recently shown that the first uranium and actinide polyiodate, UPI-1 [14], with the polyiodate unit $\mathrm{I}_{4} \mathrm{O}_{11}{ }^{2-}$ could be obtained under conditions of extreme acid addition where it was noted similar synthesis experiments with more moderate acid addition failed. It was highlighted in that investigation that, in many related studies $[11,15,16]$, heightened acid addition often results in iodate products consisting of polymerized units and this could be used as a potential means of synthesis control [14]. This theme of utilizing acidic media in synthesis control, although a relatively recent innovation, has seen further promising applications in a variety of other uranyl/actinyl structural chemical investigations. Examples can be seen in uranium and neptunium nitrate studies, including the identification acid controlled geometric isomerism in neptunium and uranium nitrates [17], and also uncovering the crystallization of uranium nitrates as an indicator of reaction competition [18]. The salient effect solution acidity has upon controlling structure formation in uranyl systems has also been recently observed in uranyl chromates and chromate-nitrates [19-21]. A further pertinent study by Nazarchuk et al. [22] demonstrated that, under decreasing $\mathrm{pH}$ conditions $(2.5 \rightarrow 1.5)$, successive organically templated uranyl sulfates would form where their structural chemistry was dependent and proportional to the specific $\mathrm{pH}$ at crystallisation. The effect of acidic conditions on redox processes was also highlighted by Langer et al. [23], in examining neptunium selenates and selenites, where acid driven disproportion was found to play a key role in determining the final $\mathrm{Np}$ and Se redox states in crystallized products. Consequently, the utilisation of acidic conditions and $\mathrm{pH}$ control, although a sensitive component, can be viewed as a route to novel and/or difficult to obtain structure formation.

Traditional interest in uranium and actinide iodate and selenite/selenate compound synthesis stems from understanding potential alteration phases that may occur in spent nuclear fuel (SNF) and in repository environments due to the prominent occurrence of I-129 and Se-79 as fission daughters [24,25]. Many of these studies were performed on what can be described as an explorative basis which left little understanding regarding chemical conditions which dictate synthesis control and outcome. However, more contemporary investigations have utilized systematic approaches, which better enable improved synthesis control and increased understanding and prediction of potential reaction outcomes [17,26-33]. Saliently, many of these more recent studies have highlighted the unique ability and promising application of uranium derived compounds in societally important materials such as radiation detectors, scintillators to proton conductors [34-36]. A key component driving these promising applications is the combination of traditional functional chemical components such as stereo-active lone pair possessing $\mathrm{IO}_{3}{ }^{-}$and $\mathrm{SeO}_{3}{ }^{2-}$ units with that of the uranium's unique chemical character as a $5 f$ element which, together, drives the properties of obtained structures to often rival or excede those of non-uranium/actinide analogues $[14,36]$. This has been exemplified by UPI- 1 and other monoiodate and monoselenite/monoselenate possessing uranyl compounds [5,6,14]. Compared to uranyl iodates, there is relatively less known about selenites and selenates in respect of synthesis conditions and control, despite the interest these receive in context of NLO and SHG materials development. Indeed, it has been more than 30 years since the first and only uranyl polyselenite was reported, $\mathrm{UO}_{2} \mathrm{Se}_{2} \mathrm{O}_{5}$, possessing the $\mathrm{Se}_{2} \mathrm{O}_{5}{ }^{2-}$ moiety [12]. Consequently, there is precedence to further understand the synthesis conditions 
of uranyl selenites and selenates both in the context of potential SNF alteration phase and for advanced functional material development.

We have recently embarked on a systematic investigation into the structure-property relations and effect of synthesis on novel SNF related actinide phase formation under variable conditions $[14,17,29-31,37,38]$. In light of the identification of the effect of acid on controlling the polymerization of iodate units in uranyl iodates [14], we have applied similar methods in the following work to investigate the effect acid has on polymerizing selenite and selenate units. In the course of our investigation we have uncovered four novel uranyl selenites/selenates including $\mathrm{Rb}_{2}\left[\left(\mathrm{UO}_{2}\right)_{2}\left(\mathrm{SeO}_{4}\right)_{3}\right], \mathrm{Rb}_{2}\left[\left(\mathrm{UO}_{2}\right)_{3}\left(\mathrm{SeO}_{3}\right)_{2} \mathrm{O}_{2}\right]$, $\mathrm{Rb}_{2}\left[\mathrm{UO}_{2}\left(\mathrm{SeO}_{4}\right)_{2}\left(\mathrm{H}_{2} \mathrm{O}\right)\right] \cdot 2 \mathrm{H}_{2} \mathrm{O}$ and pertinently $\left(\mathrm{UO}_{2}\right)_{2}\left(\mathrm{HSeO}_{3}\right)_{2}\left(\mathrm{H}_{2} \mathrm{SeO}_{3}\right)_{2} \mathrm{Se}_{2} \mathrm{O}_{5}$, only the 2nd reported uranyl selenite possessing a diselenite unit. The results of this investigation are discussed with respect to the broader family of uranyl selenites/selenates regarding the ability for acid to drive novel structure and topology formation.

\section{Experimental}

2.1. Synthesis

(a) Hydrothermal; $\mathrm{Rb}_{2}\left[\left(\mathrm{UO}_{2}\right)_{2}\left(\mathrm{SeO}_{4}\right)_{3}\right], \mathrm{Rb}_{2}\left[\left(\mathrm{UO}_{2}\right)_{3}\left(\mathrm{SeO}_{3}\right)_{2} \mathrm{O}_{2}\right]$, and $\mathrm{Rb}_{2}\left[\mathrm{UO}_{2}\left(\mathrm{SeO}_{4}\right)_{2}\right.$ $\left.\left(\mathrm{H}_{2} \mathrm{O}\right)\right] \cdot 2 \mathrm{H}_{2} \mathrm{O}$

$\mathrm{Rb}_{2}\left[\left(\mathrm{UO}_{2}\right)_{2}\left(\mathrm{SeO}_{4}\right)_{3}\right], \mathrm{Rb}_{2}\left[\left(\mathrm{UO}_{2}\right)_{3}\left(\mathrm{SeO}_{3}\right)_{2} \mathrm{O}_{2}\right]$, and $\mathrm{Rb}_{2}\left[\mathrm{UO}_{2}\left(\mathrm{SeO}_{4}\right)_{2}\left(\mathrm{H}_{2} \mathrm{O}\right)\right] \cdot 2 \mathrm{H}_{2} \mathrm{O}$ were synthesized using a similar hydrothermal method involving alike and similar reagents at different molar rations. For $\mathrm{Rb}_{2}\left[\left(\mathrm{UO}_{2}\right)_{2}\left(\mathrm{SeO}_{4}\right)_{3}\right]$ and $\mathrm{Rb}_{2}\left[\mathrm{UO}_{2}\left(\mathrm{SeO}_{4}\right)_{2}\left(\mathrm{H}_{2} \mathrm{O}\right)\right] \cdot 2 \mathrm{H}_{2} \mathrm{O}, \mathrm{RbNO}_{3}$ ( $0.03 \mathrm{~g}, 0.20 \mathrm{mmol}$, Alfa-Aesar $99.0 \% \mathrm{~min}), \mathrm{K}_{2} \mathrm{SeO}_{4}(0.03 \mathrm{~g}, 0.15 \mathrm{mmol} / 0.014 \mathrm{~g}$, $0.066 \mathrm{mmol}$, Alfa-Aesar $99.0 \% \mathrm{~min})$ and $\mathrm{UO}_{2}\left(\mathrm{NO}_{3}\right)_{2} \cdot 6 \mathrm{H}_{2} \mathrm{O}(0.05 \mathrm{~g}, 0.10 \mathrm{mmol} / 0.05 \mathrm{~g}, 0.10 \mathrm{mmol}$. International Bioanalytical Industries Inc.) were used respectively. For $\mathrm{Rb}_{2}\left[\left(\mathrm{UO}_{2}\right)_{3}\left(\mathrm{SeO}_{3}\right)_{2} \mathrm{O}_{2}\right]$ $\mathrm{RbNO}_{3}(0.03 \mathrm{~g}, 0.20 \mathrm{mmol}$, Alfa-Aesar $99.0 \% \mathrm{~min}), \mathrm{K}_{2} \mathrm{SeO}_{3}(0.014 \mathrm{~g}$, $0.066 \mathrm{mmol}$, Alfa-Aesar $99.0 \% \mathrm{~min})$ and $\mathrm{UO}_{2}\left(\mathrm{NO}_{3}\right)_{2} \cdot 6 \mathrm{H}_{2} \mathrm{O}(0.05 \mathrm{~g}, 0.10 \mathrm{mmol}$ International Bioanalytical Industries Inc.) were used. In each case, the reagents were mixed and dissolved in deionised water, $5 \mathrm{~mL}$ for $\mathrm{Rb}_{2}\left[\left(\mathrm{UO}_{2}\right)_{2}\left(\mathrm{SeO}_{4}\right)_{3}\right]$ and $10 \mathrm{~mL}$ for $\mathrm{Rb}_{2}\left[\mathrm{UO}_{2}\left(\mathrm{SeO}_{4}\right)_{2}\left(\mathrm{H}_{2} \mathrm{O}\right)\right] \cdot 2 \mathrm{H}_{2} \mathrm{O}$, and placed in Teflon lined stainless steel autoclaves. Concentrated selenic acid (60 wt.\%) was added to the reaction mixtures to reduce the $\mathrm{pH}$ to below 1 confirmed using $\mathrm{pH}$ paper. The Teflon lined stainless steel autoclaves were then secured and transferred into a box furnace. The furnace was heated to $220^{\circ} \mathrm{C}$, held there for $36 \mathrm{~h}$, and then cooled to room temperature at a rate of $3{ }^{\circ} \mathrm{C} / \mathrm{h}$. Fine greenish single crystals of the three described compounds were recovered from their respective reaction vessels and used for single crystal X-ray diffraction measurements. The crystal size was found to be approximately $30-40 \mu \mathrm{m}$ in length.

(b) Slow evaporation; $\left(\mathrm{UO}_{2}\right)_{2}\left(\mathrm{HSeO}_{3}\right)_{2}\left(\mathrm{H}_{2} \mathrm{SeO}_{3}\right)_{2} \mathrm{Se}_{2} \mathrm{O}_{5}$

$\mathrm{UO}_{2}\left(\mathrm{NO}_{3}\right)_{2} \cdot 6 \mathrm{H}_{2} \mathrm{O}(0.02 \mathrm{~g}, 0.04 \mathrm{mmol}$ International Bioanalytical Industries Inc.) and $\mathrm{H}_{2} \mathrm{SeO}_{3}(0.01 \mathrm{~g}, 0.08 \mathrm{mmol}$, Alfa-Aesar $99.0 \% \mathrm{~min})$ were dissolved in $10 \mathrm{~mL}$ of deionised water and placed in a $20 \mathrm{~mL}$ jar. Concentrated selenic acid (60 wt.\%) was added to the jar to reduce the $\mathrm{pH}$ to below 1 confirmed using $\mathrm{pH}$ paper. The jar containing the solution was placed in a fume cupboard and the solution was left to evaporate to dryness, where the formation of green fine crystals approximately $30 \mu \mathrm{m}$ in length was observed. Subsequently, they were separated for single crystal X-ray diffraction.

\subsection{Single Crystal X-ray Diffraction}

Suitable quality crystals were selected for analysis and structural refinement using single crystal X-Ray diffraction (SC-XRD). For all title compounds data were recorded with CrysAlisPro software (v.1.171.38.43) on an Agilent Oxford Diffraction Super Nova diffractometer with a Mo K $\alpha$ tube at $296 \mathrm{~K}$. Absorption corrections for the raw data were performed using the multiscan method. The unit cell was determined, and background effects were processed by the CrysAlisPro software. The initial structures of the title compounds were refined through using SHELXL-2018 within the WinGX (v1.80.05) soft- 
ware [39], and the ADDSYM algorithm of the PLATON program [40] was used for checking possible higher symmetries. Localisation of $\mathrm{H}$ atoms positions was not attempted due to unreliability as only RT data was collected. Data and crystallographic information for all compounds investigated are presented in Table 1 . These data were obtained from the Cambridge Crystallographic Data Centre (CCDC) under the numbers 2101372, 2094250, 2094251, and 2094249 for $\mathrm{Rb}_{2}\left[\left(\mathrm{UO}_{2}\right)_{2}\left(\mathrm{SeO}_{4}\right)_{3}\right], \mathrm{Rb}_{2}\left[\mathrm{UO}_{2}\left(\mathrm{SeO}_{4}\right)_{2}\left(\mathrm{H}_{2} \mathrm{O}\right)\right] \cdot 2 \mathrm{H}_{2} \mathrm{O}, \mathrm{Rb}_{2}\left[\left(\mathrm{UO}_{2}\right)_{3}\left(\mathrm{SeO}_{3}\right)_{2} \mathrm{O}_{2}\right]$, and $\left(\mathrm{UO}_{2}\right)_{2}\left(\mathrm{HSeO}_{3}\right)\left(\mathrm{H}_{2} \mathrm{SeO}_{3}\right)_{2} \mathrm{Se}_{2} \mathrm{O}_{5}$, respectively.

Table 1. Crystallographic data for all phases reported in this work.

\begin{tabular}{|c|c|c|c|c|}
\hline Compound & $\mathrm{Rb}_{2}\left[\left(\mathrm{UO}_{2}\right)_{2}\left(\mathrm{SeO}_{4}\right)_{3}\right]$ & $\mathrm{Rb}_{2}\left[\left(\mathrm{UO}_{2}\right)_{3}\left(\mathrm{SeO}_{3}\right)_{2} \mathrm{O}_{2}\right]$ & $\mathrm{Rb}_{2}\left[\mathrm{UO}_{2}\left(\mathrm{SeO}_{4}\right)_{2}\left(\mathrm{H}_{2} \mathrm{O}\right)\right] \cdot 2 \mathrm{H}_{2} \mathrm{O}$ & $\left(\mathrm{UO}_{2}\right)_{2}\left(\mathrm{HSeO}_{3}\right)_{2}\left(\mathrm{H}_{2} \mathrm{SeO}_{3}\right)_{2} \mathrm{Se}_{2} \mathrm{O}_{5}$ \\
\hline $\begin{array}{l}\text { Formula } \\
\text { weight }\end{array}$ & 2279.76 & 1210.88 & 1549.78 & 1285.82 \\
\hline $\begin{array}{l}\text { Crystal } \\
\text { system }\end{array}$ & Tetragonal & Triclinic & Orthorhombic & Orthorhombic \\
\hline $\begin{array}{l}\text { Space } \\
\text { group }\end{array}$ & $\mathrm{P}_{2} / \mathrm{ncm}$ & $P \overline{1}$ & $P m n 2_{1}$ & $\mathrm{Cmc}_{1}$ \\
\hline$a(\AA)$ & $9.8312(4)$ & $7.0116(6)$ & $13.041(3)$ & 28.4752(12) \\
\hline$b(\AA)$ & $9.8312(4)$ & $7.0646(6)$ & $8.579(2)$ & $6.3410(3)$ \\
\hline$c(\AA)$ & $15.4924(9)$ & $8.1793(7)$ & $11.583(2)$ & $10.8575(6)$ \\
\hline$\alpha\left(^{\circ}\right)$ & 90 & $103.318(7)$ & 90 & 90 \\
\hline$\beta\left(^{\circ}\right)$ & 90 & $105.968(7)$ & 90 & 90 \\
\hline$\gamma\left({ }^{\circ}\right)$ & 90 & $100.642(7)$ & 90 & 90 \\
\hline $\begin{array}{l}\text { Volume } \\
\left(\AA^{3}\right)\end{array}$ & 1497.38(15) & $365.48(6)$ & $1295.9(5)$ & $1960.45(16)$ \\
\hline $\begin{array}{c}\text { Flack } \\
\text { Parameter }\end{array}$ & 0 & 0 & $-0.009(12)$ & $-0.005(14)$ \\
\hline $\begin{array}{c}\mathrm{Z} / \mu \\
\left(\mathrm{mm}^{-1}\right)\end{array}$ & $2 / 35.435$ & $1 / 42.639$ & $2 / 25.663$ & $4 / 27.737$ \\
\hline$F(000)$ & 1952.0 & 505.7 & 1352.0 & 2224.0 \\
\hline $\begin{array}{c}d_{\text {calcd }}(\mathrm{g} \\
\left.\mathrm{cm}^{-3}\right)\end{array}$ & 5.056 & 5.502 & 3.972 & 4.357 \\
\hline GOF & 1.023 & 1.018 & 0.956 & 0.859 \\
\hline $\begin{array}{l}\text { Final } R_{1}{ }^{a} \\
{[I>2 \sigma(I)]}\end{array}$ & 0.0459 & 0.0643 & 0.0481 & 0.0377 \\
\hline $\begin{array}{c}\text { Final } w R_{2} \\
\quad{ }^{b}[I> \\
2 \sigma(I)]\end{array}$ & 0.1374 & 0.1751 & 0.1045 & 0.1097 \\
\hline S & 1.023 & 1.018 & 0.956 & 0.859 \\
\hline
\end{tabular}

${ }^{a} \mathrm{R}_{1}=\sum|| F_{o}|-| F_{c}|| / \sum\left|F_{o}\right|,{ }^{b} w \mathrm{R}_{2}=\left\{\sum w\left[\left(F_{o}\right)^{2}-\left(F_{c}\right)^{2}\right]^{2} / \sum w\left[\left(F_{o}\right)^{2}\right]^{2}\right\}^{\frac{1}{2}}$.

\subsection{Bond Valence Sums}

Bond valence sums (BVS) calculations were undertaken for the cations in $\mathrm{Rb}_{2}\left[\left(\mathrm{UO}_{2}\right)_{2}\left(\mathrm{SeO}_{4}\right)_{3}\right], \quad \mathrm{Rb}_{2}\left[\left(\mathrm{UO}_{2}\right)_{3}\left(\mathrm{SeO}_{3}\right)_{2} \mathrm{O}_{2}\right], \quad \mathrm{Rb}_{2}\left[\mathrm{UO}_{2}\left(\mathrm{SeO}_{4}\right)_{2}\left(\mathrm{H}_{2} \mathrm{O}\right)\right] \cdot 2 \mathrm{H}_{2} \mathrm{O}$, and $\left(\mathrm{UO}_{2}\right)_{2}\left(\mathrm{HSeO}_{3}\right)_{2}\left(\mathrm{H}_{2} \mathrm{SeO}_{3}\right)_{2} \mathrm{Se}_{2} \mathrm{O}_{5}$ using the parameters reported by Burns and coworkers [41] for seven-coordinate U. The parameters provided by Brese and $\mathrm{O}^{\prime}$ Keeffe [42] were used for Se and O.

\section{Results and Discussion}

\subsection{Structural Studies (a) $\mathrm{Rb}_{2}\left[\left(\mathrm{UO}_{2}\right)_{2}\left(\mathrm{SeO}_{4}\right)_{3}\right]$}

$\mathrm{Rb}_{2}\left[\left(\mathrm{UO}_{2}\right)_{2}\left(\mathrm{SeO}_{4}\right)_{3}\right]$ synthesized using a hydrothermal method was found to adopt a tetragonal structure in space group $P 4_{2} / \mathrm{hcm}$ with $a=9.8312(4) \AA, c=15.4924(9) \AA$ and $V=1497.38(15) \AA^{3}$ using SC-XRD measurements. The structure consists of seven coordinate $\mathrm{U}$ atoms which form $\mathrm{UO}_{7}$ pentagonal bipyramid polyhedra with two short axial and collinear oxo $\mathrm{U}=\mathrm{O}$ bonds of 1.741(11) $\AA$, consistent with the uranyl bond in the hexavalent state. Surrounding the uranyl groups equatorially in the $\mathrm{UO}_{7}$ polyhedra are five $\mathrm{U}-\mathrm{O}$ bonds ranging in length from 2.372(11) to 2.400(10) $\AA$ which are provided by coordinating $\mathrm{SeO}_{4}{ }^{2-}$ 
ligands fivefold (Figure 1). The Se-O bond lengths were found to range from 1.59(5) to 1.656(11) $\AA$. The $\mathrm{UO}_{2}\left(\mathrm{SeO}_{4}\right)_{5}{ }^{8-}$ units link with others in a corner sharing motif to form $\left[\left(\mathrm{UO}_{2}\right)_{4}\left(\mathrm{SeO}_{4}\right)_{6}\right]^{4-}$ sheets in the [110] plane (Figure 1). The sheets are observed to adopt a corrugated motif viewing from the [100] direction (Figure 1a) in which $\mathrm{Rb}^{+}$cations are located in the interlayer space. The SC-XRD structural solution indicated that the $\mathrm{O}(6)$ was positionally disordered and this is illustrated in Figure $1 \mathrm{~b}$ where the disordering occurs parallel to the a-b plane. BVS values of $6.11,6.16$, and 6.09 were determined for the U(1), $\mathrm{Se}(1)$, and $\mathrm{Se}(2)$ positions, supporting the occurrence of hexavalent states for $\mathrm{U}$ and $\mathrm{Se}$ in the structure of $\mathrm{Rb}_{2}\left[\left(\mathrm{UO}_{2}\right)_{2}\left(\mathrm{SeO}_{4}\right)_{3}\right]$. Full BVS values are given in Table 2.

Table 2. BVS calculations for $\mathrm{Rb}_{2}\left[\left(\mathrm{UO}_{2}\right)_{2}\left(\mathrm{SeO}_{4}\right)_{3}\right]$.

\begin{tabular}{ccccccc}
\hline & $\mathbf{U}$ & $\mathbf{S e}(\mathbf{1})$ & $\mathbf{S e}(\mathbf{2})$ & $\mathbf{R b}(\mathbf{1})$ & $\mathbf{R b}(\mathbf{2})$ & $\Sigma$ \\
\hline O1 & 1.717 & & & $0.116^{\times 2 \downarrow}$ & & 1.83 \\
O2 & 0.543 & & 1.55 & & & 2.09 \\
O3 & 1.800 & & & $0.121^{\times 2 \downarrow}$ & & 1.92 \\
O4 & $0.498^{\times 2 \downarrow}$ & & $1.430^{\times 2 \downarrow}$ & $0.053^{\times 4 \downarrow}$ & $0.058^{\times 4 \downarrow}$ & 2.04 \\
O5 & $0.526^{\times 2 \downarrow}$ & $1.540^{\times 4 \downarrow}$ & & & $0.087^{\times 4 \downarrow}$ & 2.15 \\
O6 & & & 1.68 & $0.073^{\times 4 \downarrow}$ & $0.052^{\times 4 \downarrow}$ & 1.81 \\
\hline$\Sigma$ & 6.11 & 6.16 & 6.09 & 0.96 & 0.79 & \\
\hline
\end{tabular}

*Arrow corresponds to calculation direction.

A notable observation of $\mathrm{Rb}_{2}\left[\left(\mathrm{UO}_{2}\right)_{2}\left(\mathrm{SeO}_{4}\right)_{3}\right]$ is the corrugation of the $\left[\left(\mathrm{UO}_{2}\right)_{4}\left(\mathrm{SeO}_{4}\right)_{6}\right]^{4-}$ sheets. It is typical of uranyl bearing compounds to form $2 \mathrm{D}$ layered or 1D chain structures due to the oxo-bond nature of the uranyl group [43]. Deformation of the structure or occurrence of corrugation in layers often occurs through factors, such as the application of pressure during synthesis [30,37,44], non-spherical interlayer ions [45], or the unideal coordination of layer ions $[30,46]$, where the structures or layers deform accordingly to accommodate these. In the case of $\mathrm{Rb}_{2}\left[\left(\mathrm{UO}_{2}\right)_{2}\left(\mathrm{SeO}_{4}\right)_{3}\right]$, the relatively simplistic formula would suggest a less distorted structure, however the occurrence of $\mathrm{UO}_{7}$ and $\mathrm{SeO}_{4}$ polyhedra results in the latter of the described examples. The $\mathrm{Se}(1) \mathrm{O}_{4}$ polyhedra is able to satisfactorily fourfold coordinate to uranyl centres, whereas the $\mathrm{Se}(2) \mathrm{O}_{4}$ polyhedra can only threefold coordinate, which leaves a vacant Se-O ligand that is positionally disordered. Accordingly, it is suspected that this unideal coordination of $\mathrm{SeO}_{4}$ polyhedra due to the occurrence $\mathrm{UO}_{7}$ will lead to corrugation of the layers and the occurrence of disorder. Indeed, the same sheet corrugation is observed in $\mathrm{Cs}_{2}\left[\left(\mathrm{UO}_{2}\right)_{2}\left(\mathrm{CrO}_{4}\right)_{3}\right]$ [19] and $[\mathrm{pyH}]_{2}\left[\left(\mathrm{UO}_{2}\right)_{2}\left(\mathrm{SO}_{4}\right)_{3}\right]$ [22] which respectively form tetragonal (SG $\left.P \overline{4} 2_{1} \mathrm{~m}\right)$ and orthorhombic (SG C222 1 ) structures. Very similar to $\mathrm{Rb}_{2}\left[\left(\mathrm{UO}_{2}\right)_{2}\left(\mathrm{SeO}_{4}\right)_{3}\right]$, the two Cr positions in $\mathrm{Cs}_{2}\left[\left(\mathrm{UO}_{2}\right)_{2}\left(\mathrm{CrO}_{4}\right)_{3}\right], \mathrm{Cr}(1) \mathrm{O}_{4}$ and $\mathrm{Cr}(2) \mathrm{O}_{4}$, threefold and fourfold coordinate to the $\mathrm{UO}_{7}$ polyhedra. This is also observed in $[\mathrm{pyH}]_{2}\left[\left(\mathrm{UO}_{2}\right)_{2}\left(\mathrm{SO}_{4}\right)_{3}\right]$ for the two Se positions, $\mathrm{Se}(1) \mathrm{O}_{4}$ and $\mathrm{Se}(2) \mathrm{O}_{4}$, four and three fold coordinating the $\mathrm{UO}_{7}$ polyhedra however the structure is further directed by hydrogen bonding from the $\mathrm{pyH}^{+}$groups to the $\mathrm{Se}(2) \mathrm{O}_{4}$ polyhedra. Similarly, topological arrangements can be found in $\mathrm{Cs}_{2}\left[\left(\mathrm{UO}_{2}\right)_{2}\left(\mathrm{SO}_{4}\right)_{3}\right]$ [47] and $\beta-\mathrm{Cs}_{2}\left[\left(\mathrm{UO}_{2}\right)_{2}\left(\mathrm{MoO}_{4}\right)_{3}\right][48]$. 
(a)

(b)

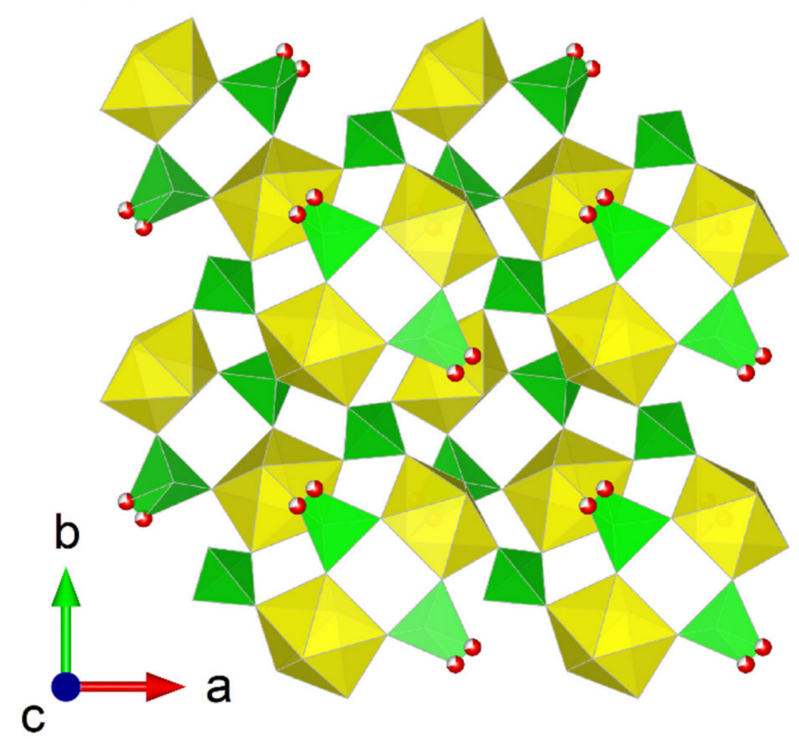

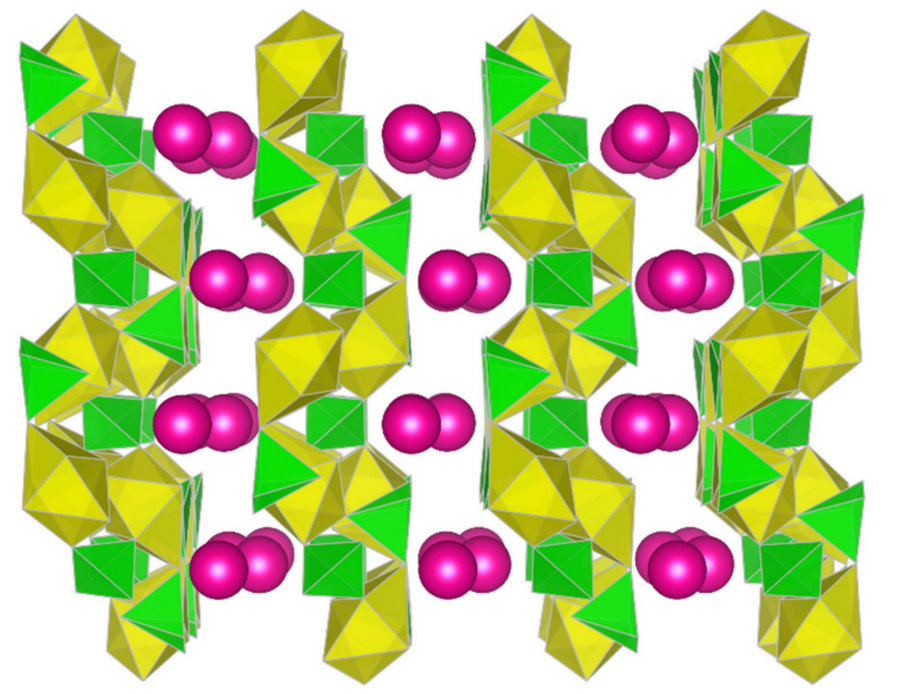

b
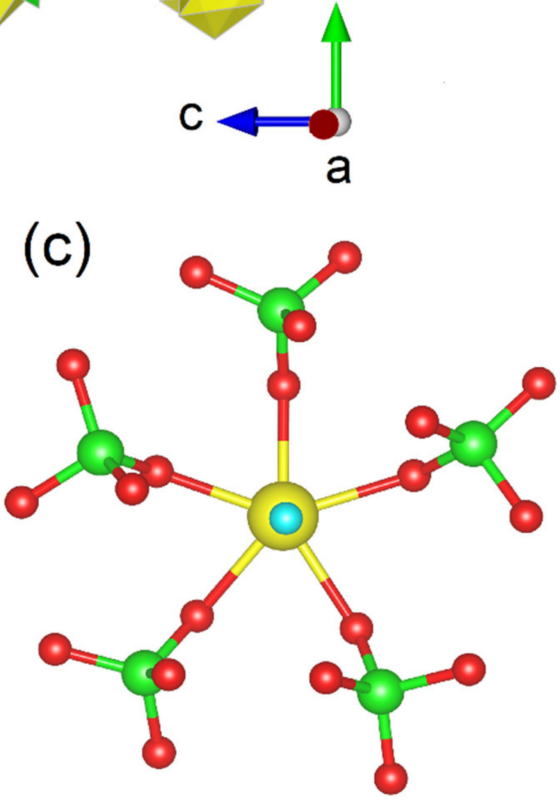

Figure 1. Structural representation of orthorhombic $\mathrm{Rb}_{2}\left[\left(\mathrm{UO}_{2}\right)_{2}\left(\mathrm{SeO}_{4}\right)_{3}\right]$ in space group $P 4_{2} / n c m$ in (a) general representation, (b) in the [001] direction illustrating the layer configuration of the structure and also disordered $\mathrm{O}(6)$ oxygens, and (c) highlighting the coordination motif of $\mathrm{UO}_{2}\left(\mathrm{SeO}_{4}\right)^{8-}$ units. Note yellow polyhedra, green polyhedra, green spheres, yellow spheres, red spheres and blue spheres respectively represent $\mathrm{UO}_{7}, \mathrm{SeO}_{4}, \mathrm{Se}, \mathrm{U}, \mathrm{O}$ and uranyl $\mathrm{O}$ units/atoms respectively.

\subsection{Structural Studies (b) $\mathrm{Rb}_{2}\left[\left(\mathrm{UO}_{2}\right)_{3}\left(\mathrm{SeO}_{3}\right)_{2} \mathrm{O}_{2}\right]$}

$\mathrm{Rb}_{2}\left[\left(\mathrm{UO}_{2}\right)_{3}\left(\mathrm{SeO}_{3}\right)_{2} \mathrm{O}_{2}\right]$ synthesized using a hydrothermal method was found to adopt a triclinic structure in space group $P \overline{1}$ with $a=7.0116(6) \AA, b=7.0646(6) \AA, c=8.1793(7) \AA$, $\alpha=103.318(7)^{\circ}, \beta=105.968(7)^{\circ}, \gamma=100.642(7)^{\circ}$ and $V=365.48(6) \AA^{3}$ using SC-XRD measurements. The structure consists of seven and eight coordinate $U$ atoms which form respectively $\mathrm{UO}_{7}$ pentagonal and $\mathrm{UO}_{8}$ hexagonal bipyramid polyhedra. Both the $\mathrm{UO}_{7}$ and $\mathrm{UO}_{8}$ polyhedra possess two short axial and collinear oxo $\mathrm{U}=\mathrm{O}$ bonds of $1.775(16) / 1.809(17)$ and 1.815(16) $\AA$, respectively, consistent with the uranyl group with hexavalent $\mathrm{U}$ in the respective coordination geometry. Surrounding the uranyl groups equatorially in the $\mathrm{UO}_{7}$ polyhedra are five U-O bonds ranging in length from 2.245(13) to 2.426(12) $\AA$, which are provided by two $\mathrm{SeO}_{3}{ }^{2-}$ ligands, one corner sharing and the other edge sharing, and two oxygen atoms from neighboring $\mathrm{UO}_{8}$ polyhedra. Surrounding the uranyl groups 
equatorially in the $\mathrm{UO}_{8}$ polyhedra are six oxygen atoms, where four of them are provided by two $\mathrm{SeO}_{3}{ }^{2-}$ ligands in an edge sharing motif and the other two from oxygen atoms via corner sharing (Figure 2). The $\mathrm{SeO}_{3}{ }^{2-}$ ligands have Se-O bonds lengths ranging from 1.681(16) to 1.682(12) $\AA$. The $\mathrm{UO}_{7}$ and $\mathrm{UO}_{8}$ are observed to link together parallel to the [010] direction, forming discrete chains which are linked together by $\mathrm{SeO}_{3}{ }^{2-}$ that create infinite layers normal to the [101] plane (Figure 2). Between the layers $\mathrm{Rb}^{+}$cations are observed where the structural model indicates they are partially disordered. BVS values of 5.74, 6.12, and 4.26 were determined for the $\mathrm{U}(1), \mathrm{U}(2)$, and $\mathrm{Se}(1)$ positions, supporting the respective occurrence of hexavalent and tetravalent $\mathrm{U}$ and $\mathrm{Se}$ in the structure of $\mathrm{Rb}_{2}\left[\left(\mathrm{UO}_{2}\right)_{3}\left(\mathrm{SeO}_{3}\right)_{2} \mathrm{O}_{2}\right]$. Full BVS values are given in Table 3.

Table 3. BVS calculations for $\mathrm{Rb}_{2}\left[\left(\mathrm{UO}_{2}\right)_{3}\left(\mathrm{SeO}_{3}\right)_{2} \mathrm{O}_{2}\right]$.

\begin{tabular}{|c|c|c|c|c|c|}
\hline & $\mathrm{U}(1)$ & $\mathrm{U}(2)$ & $\operatorname{Se}(1)$ & $R b(1)$ & $\Sigma$ \\
\hline O1 & $0.361^{x 2 \downarrow}$ & 0.473 & 1.418 & & 2.30 \\
\hline $\mathrm{O} 2$ & $1.570 \times 2 \downarrow$ & & & $\begin{array}{c}0.196+0.151 \\
\downarrow\end{array}$ & 1.91 \\
\hline $\mathrm{O} 3$ & & 1.59 & & $\begin{array}{c}0.206+0.184 \\
\downarrow\end{array}$ & 1.98 \\
\hline $\mathrm{O} 4$ & & 1.70 & & 0.198 & 1.90 \\
\hline O5 & & 0.529 & 1.421 & 0.204 & 2.154 \\
\hline O6 & $0.274^{\times 2 \downarrow}$ & 0.510 & 1.415 & 0.0390 & 2.24 \\
\hline O7 & $0.665^{x 2 \downarrow}$ & $0.675^{\times 2 \downarrow}$ & & 0.105 & 1.44 \\
\hline$\Sigma$ & 5.74 & 6.12 & 4.26 & 1.28 & \\
\hline
\end{tabular}

${ }^{*}$ Arrow corresponds to calculation direction.

$\mathrm{Rb}_{2}\left[\left(\mathrm{UO}_{2}\right)_{3}\left(\mathrm{SeO}_{3}\right)_{2} \mathrm{O}_{2}\right]$, although possessing a different structure, can be topologically related through its sheet motif to that of $\mathrm{Sr}\left[\left(\mathrm{UO}_{2}\right)_{3}\left(\mathrm{SeO}_{3}\right)_{2} \mathrm{O}_{2}\right] \cdot \mathrm{H}_{2} \mathrm{O}(\mathrm{SG} \mathrm{C} 2 / m)$ [49], $\mathrm{Li}_{2}\left[\left(\mathrm{UO}_{2}\right)_{3}\left(\mathrm{SeO}_{3}\right)_{2} \mathrm{O}_{2}\right] \cdot \mathrm{H}_{2} \mathrm{O}\left(\mathrm{SG} P 2_{1} / \mathrm{c}\right)$ [50], as well as the minerals guilleminite, $\left.\mathrm{Ba}\left[\left(\mathrm{UO}_{2}\right)_{3} \mathrm{SeO}_{3}\right)_{2} \mathrm{O}_{2}\right] \cdot 4 \mathrm{H}_{2} \mathrm{O}\left(\mathrm{SG} P 2_{1} n m\right)[51,52]$, and marthozite, $\mathrm{Cu}\left[\left(\mathrm{UO}_{2}\right)_{3}\left(\mathrm{SeO}_{3}\right)_{2} \mathrm{O}_{2}\right] \cdot 8 \mathrm{H}_{2} \mathrm{O}$ $\left(\mathrm{SG} P b n 2_{1}\right.$ ) [53]. In all these, chains are constructed through edge-sharing $\mathrm{UO}_{6}$ and $\mathrm{UO}_{7}$ polyhedra that link to form sheets via $\mathrm{SeO}_{3}$ units through a phosphuranylite anion topology [52]. It was noted by Gurzhiy et al. [52], when comparing these natural and synthetic selenites, that they are contrastingly described by different orientation matrices, in that the latter example possess layers which are described by the $c 2 / m$ space group, whereas for the former structures, layers demonstrate higher symmetry with a pmmn description. Furthermore, when observing $\mathrm{Rb}_{2}\left[\left(\mathrm{UO}_{2}\right)_{3}\left(\mathrm{SeO}_{3}\right)_{2} \mathrm{O}_{2}\right]$, this follows where its layer topology is better described in the lower symmetry subset. 

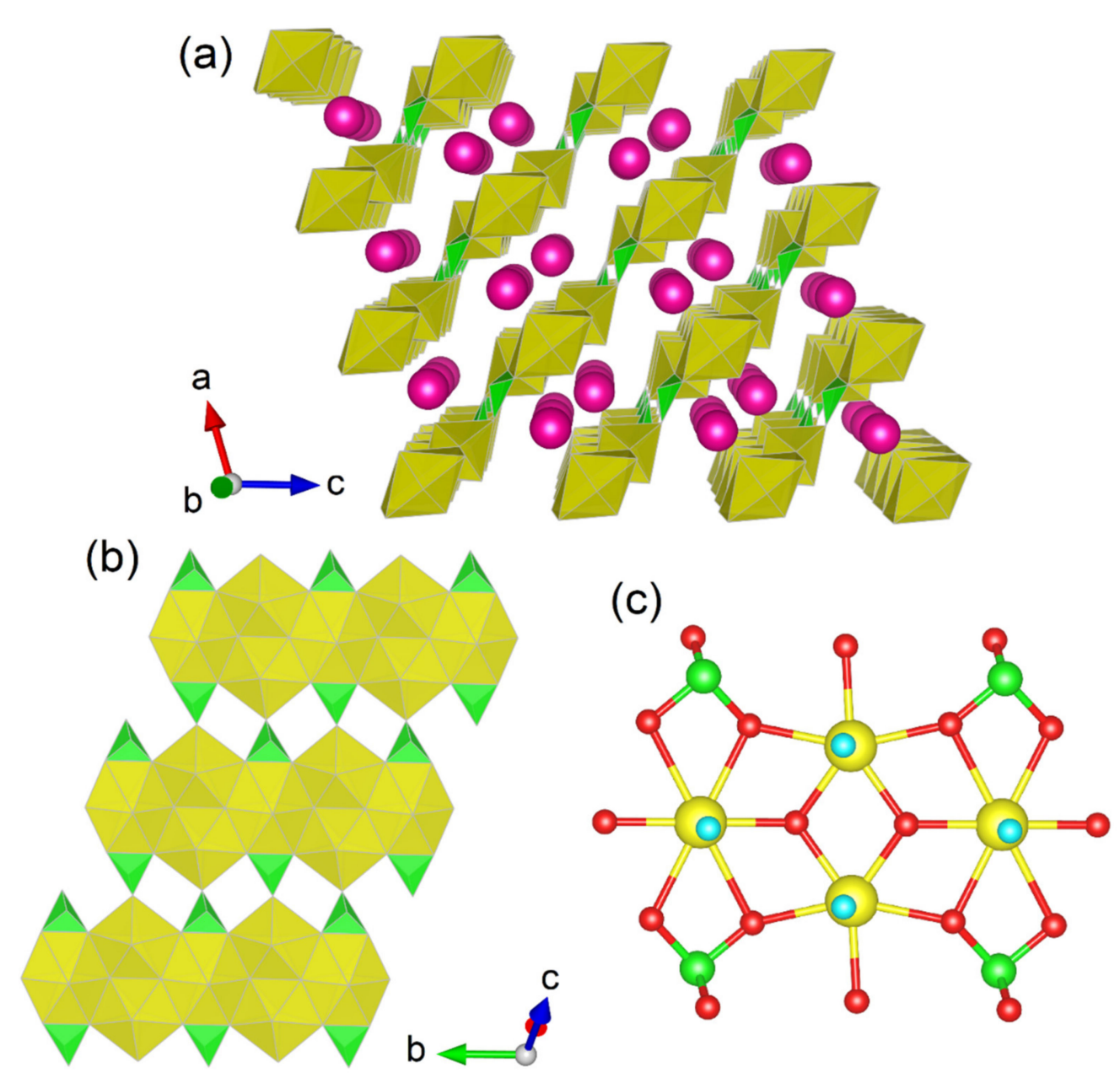

Figure 2. Structural representation of triclinic $\mathrm{Rb}_{2}\left[\left(\mathrm{UO}_{2}\right)_{3}\left(\mathrm{SeO}_{3}\right)_{2} \mathrm{O}_{2}\right]$ in space group $\mathrm{P} \overline{1}$ (a) general representation, (b) illustrating the layer configuration of the structure and (c) highlighting the coordination motif of $\mathrm{UO}_{7}$ and $\mathrm{SeO}_{3}$ units. Note yellow polyhedra, green polyhedra, green spheres, yellow spheres, red spheres and blue spheres respectively represent $\mathrm{UO}_{7}, \mathrm{SeO}_{3}, \mathrm{Se}, \mathrm{U}, \mathrm{O}$ and uranyl $\mathrm{O}$ units/atoms respectively.

\subsection{Structural Studies (c) $\mathrm{Rb}_{2}\left[\mathrm{UO}_{2}\left(\mathrm{SeO}_{4}\right)_{2}\left(\mathrm{H}_{2} \mathrm{O}\right)\right] \cdot 2 \mathrm{H}_{2} \mathrm{O}$}

$\mathrm{Rb}_{2}\left[\mathrm{UO}_{2}\left(\mathrm{SeO}_{4}\right)_{2}\left(\mathrm{H}_{2} \mathrm{O}\right)\right] \cdot 2 \mathrm{H}_{2} \mathrm{O}$ synthesized using a hydrothermal method was found to adopt an orthorhombic structure in space group $P m n 2_{1}$ where with $a=13.041$ (3) $\AA$, $b=8.579(2) \AA, c=11.583(2) \AA$ and $V=1295.9(5) \AA^{3}$ using SC-XRD measurements. The structure consists of seven coordinate $\mathrm{U}$ atoms which form $\mathrm{UO}_{7}$ pentagonal bipyramid polyhedra that contain two short axial and collinear oxo $U=O$ bonds of $1.765(10) \AA$ consistent with the uranyl group for hexavalent $\mathrm{U}$ in this coordination geometry. Surrounding the uranyl group equatorially in the $\mathrm{UO}_{7}$ polyhedra are five oxygen atoms corner-sharing provided by four $\mathrm{SeO}_{4}{ }^{2-}$ ligands and one oxygen atom. BVS calculation of the lone oxygen ligand donor $(\mathrm{O}(2))$ produces a low value of 0.60 consistent with an aqua $\mathrm{H}_{2} \mathrm{O}$ coordinating ligand (Figure 3c). The $\mathrm{SeO}_{4}{ }^{2-}$ ligands act to link $\mathrm{UO}_{7}$ polyhedra in the [001] direction forming infinite chains (Figure 3). Between the chains parallel to the [010] direction, $\mathrm{Rb}$ cations are observed with $\mathrm{H}_{2} \mathrm{O}$ molecules where, between the chains parallel to the [001] direction, the inter-space is free (Figure 3). BVS values of 6.19, 6.17, and 6.09 were determined for the $\mathrm{U}(1), \mathrm{Se}(1)$, and $\mathrm{Se}(2)$ positions, supporting the occurrence of hexavalent states for $\mathrm{U}$ and $\mathrm{Se}$ in the structure of $\mathrm{Rb}_{2}\left[\mathrm{UO}_{2}\left(\mathrm{SeO}_{4}\right)_{2}\left(\mathrm{H}_{2} \mathrm{O}\right)\right] \cdot 2 \mathrm{H}_{2} \mathrm{O}$. Full BVS values are given in Table 4. 
(b)

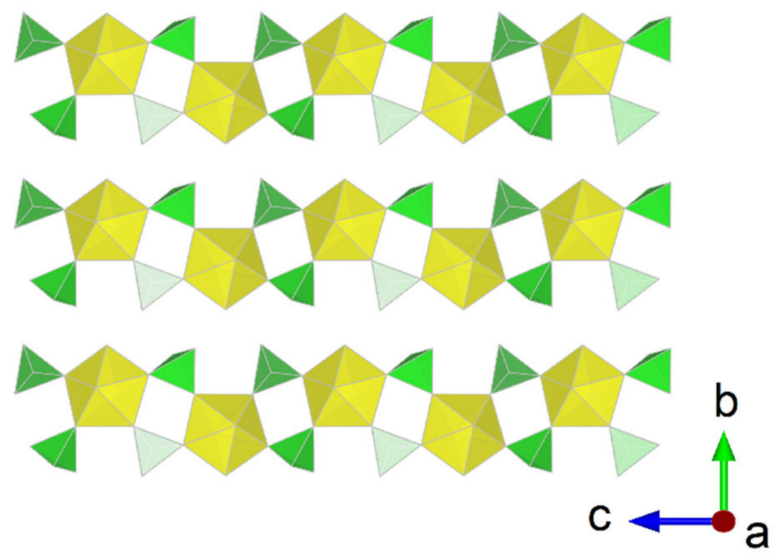

(a)
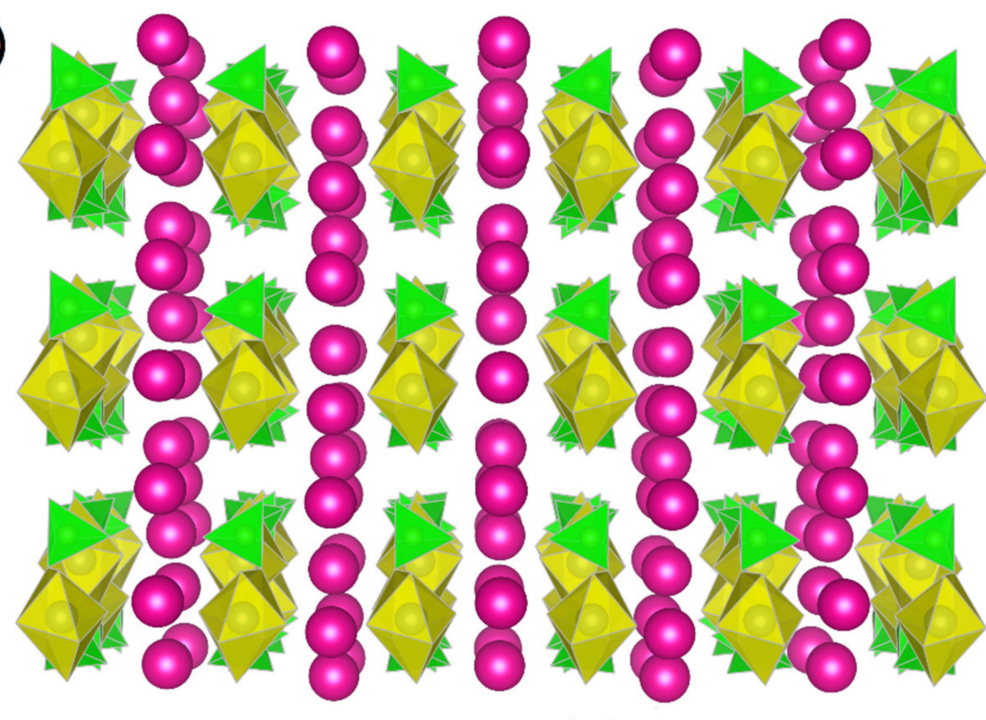

(c)
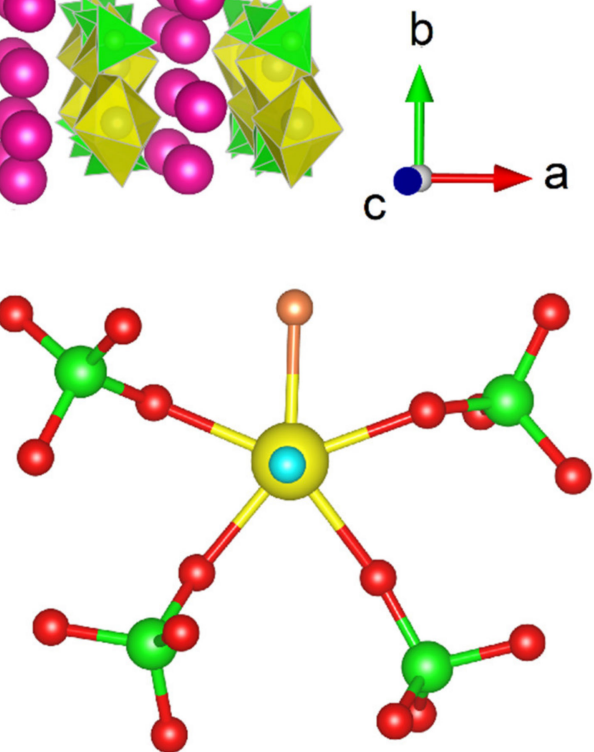

Figure 3. Structural representation of orthorhombic $\mathrm{Rb}_{2}\left[\mathrm{UO}_{2}\left(\mathrm{SeO}_{4}\right)_{2}\left(\mathrm{H}_{2} \mathrm{O}\right)\right] \cdot 2 \mathrm{H}_{2} \mathrm{O}$ in space group Pmn2 1 (a) general representation, (b) in the [100] direction illustrating the layer configuration of the structure and (c) highlighting the coordination motif of $\mathrm{UO}_{7}$ and $\mathrm{SeO}_{4}$ units. Note yellow polyhedra, green polyhedra, green spheres, yellow spheres, red spheres, blue spheres and orange spheres respectively represent $\mathrm{UO}_{7}, \mathrm{SeO}_{3}, \mathrm{Se}, \mathrm{U}, \mathrm{O}$, uranyl $\mathrm{O}$ and aqua $\mathrm{O}$ units/atoms respectively.

Table 4. BVS calculations for $\mathrm{Rb}_{2}\left[\mathrm{UO}_{2}\left(\mathrm{SeO}_{4}\right)_{2}\left(\mathrm{H}_{2} \mathrm{O}\right)\right] \cdot 2 \mathrm{H}_{2} \mathrm{O}$.

\begin{tabular}{|c|c|c|c|c|c|c|c|c|}
\hline & $\mathbf{U}$ & $\operatorname{Se}(1)$ & $\operatorname{Se}(2)$ & $\mathrm{Rb}(\mathbf{1})$ & $R b(2)$ & $R b(3)$ & $\mathrm{Rb}(4)$ & $\Sigma$ \\
\hline O1 & 0.533 & 1.404 & & & & & & 1.94 \\
\hline $\mathrm{O} 2$ & 0.466 & & & & & & 0.138 & 0.60 \\
\hline $\mathrm{O} 3$ & 0.557 & & 1.480 & & & & 0.138 & 2.175 \\
\hline $\mathrm{O} 4$ & $1.762^{\wedge}$ & & & & $0.090 \times 2 \downarrow$ & $0.115^{\times 2 \downarrow}$ & & 1.957 \\
\hline O5 & & & & & 0.094 & 0.135 & & 0.229 \\
\hline O6 & 0.582 & & 1.429 & & & & & 2.011 \\
\hline O7 & 1.732 & & & $0.088^{x 2 \downarrow}$ & & $0.070 \times 2 \downarrow$ & & 1.89 \\
\hline O8 & & & 1.598 & $0.160 \times 2 \downarrow$ & $0.065^{\times 2 \downarrow}$ & $0.074 \times 2 \downarrow$ & & 1.897 \\
\hline O9 & & 1.581 & & $0.148^{\times 2 \downarrow}$ & & & $0.101 \times 2 \downarrow$ & 1.83 \\
\hline O10 & & 1.627 & & & $0.150 \times 2 \downarrow$ & $0.109 \times 2 \downarrow$ & & 1.886 \\
\hline O11 & 0.553 & 1.563 & & & & $0.050^{x 2 \downarrow}$ & & 2.011 \\
\hline O12 & & & 1.590 & & & & $0.080 \times 2 \downarrow$ & 1.67 \\
\hline O13 & & & & 0.095 & & & 0.050 & 0.145 \\
\hline O14 & & & & & 0.010 & & 0.185 & 0.20 \\
\hline O15 & & & & 0.105 & & & 0.114 & 0.219 \\
\hline$\Sigma$ & 6.19 & 6.17 & 6.09 & 1.00 & 0.80 & 0.97 & 0.99 & \\
\hline
\end{tabular}

*Arrow corresponds to calculation direction. 
The structure of $\mathrm{Rb}_{2}\left[\mathrm{UO}_{2}\left(\mathrm{SeO}_{4}\right)_{2}\left(\mathrm{H}_{2} \mathrm{O}\right)\right] \cdot 2 \mathrm{H}_{2} \mathrm{O}$ bares strong similarity to that of previously reported $\mathrm{Rb}_{2}\left[\mathrm{UO}_{2}\left(\mathrm{SeO}_{4}\right)_{2}\left(\mathrm{H}_{2} \mathrm{O}\right)\right] \cdot \mathrm{H}_{2} \mathrm{O}$ also orthorhombic but in space group $\mathrm{Pna2}_{1}[54,55]$. Both structures contain the same layer-chain configuration with aqua ligands extending off uranyl centres alternatively along the layer direction (Figure $3 \mathrm{~b}$ ). However the increase in the degree of hydration of $\mathrm{Rb}_{2}\left[\mathrm{UO}_{2}\left(\mathrm{SeO}_{4}\right)_{2}\left(\mathrm{H}_{2} \mathrm{O}\right)\right] \cdot 2 \mathrm{H}_{2} \mathrm{O}$ compared to $\mathrm{Rb}_{2}\left[\mathrm{UO}_{2}\left(\mathrm{SeO}_{4}\right)_{2}\left(\mathrm{H}_{2} \mathrm{O}\right)\right] \cdot \mathrm{H}_{2} \mathrm{O}$ results in a change of symmetry as well as an increase in unit cell volume $\left(1295.9(5)\right.$ vs. $1240.4(3) \AA^{3}$ respectively [54]). The influence of the degree of hydration has been demonstrated to play a subtle but significant role in the formation of thorium nitrates [56] as well as uranium and neptunium nitrates [17] where changes to the number of $\mathrm{H}_{2} \mathrm{O}$ units present can lead to variability in structure formation often modulated through the presence of specific counter ions present. Accordingly, the subtle structural variation between $\mathrm{Rb}_{2}\left[\mathrm{UO}_{2}\left(\mathrm{SeO}_{4}\right)_{2}\left(\mathrm{H}_{2} \mathrm{O}\right)\right] \cdot 2 \mathrm{H}_{2} \mathrm{O}$ and $\mathrm{Rb}_{2}\left[\mathrm{UO}_{2}\left(\mathrm{SeO}_{4}\right)_{2}\left(\mathrm{H}_{2} \mathrm{O}\right)\right] \cdot \mathrm{H}_{2} \mathrm{O}$ is suspected to be due to this difference. Furthermore, controlling the degree of hydration in structure formation can be a difficult task from a synthesis perspective particularly when like counter cations are present. The application of hydrothermal conditions, which involve a heightened degree of pressure in the synthesis of $\mathrm{Rb}_{2}\left[\mathrm{UO}_{2}\left(\mathrm{SeO}_{4}\right)_{2}\left(\mathrm{H}_{2} \mathrm{O}\right)\right] \cdot 2 \mathrm{H}_{2} \mathrm{O}$ compared to the slow evaporation conditions used for $\mathrm{Rb}_{2}\left[\mathrm{UO}_{2}\left(\mathrm{SeO}_{4}\right)_{2}\left(\mathrm{H}_{2} \mathrm{O}\right)\right] \cdot \mathrm{H}_{2} \mathrm{O}$ [54] are suspected to lead to the increased hydration of the former structure. Further, it is noteworthy that the observed topology of the uranyl-selenate chains in $\mathrm{Rb}_{2}\left[\mathrm{UO}_{2}\left(\mathrm{SeO}_{4}\right)_{2}\left(\mathrm{H}_{2} \mathrm{O}\right)\right] \cdot 2 \mathrm{H}_{2} \mathrm{O}$ can be observed in the natural uranyl sulfate minerals bobcookite, $\mathrm{NaAl}\left(\mathrm{UO}_{2}\right)_{2}\left(\mathrm{SO}_{4}\right)_{4} \cdot 18 \mathrm{H}_{2} \mathrm{O}$ [57], and svornostite, $\mathrm{K}_{2} \mathrm{Mg}\left[\left(\mathrm{UO}_{2}\right)\left(\mathrm{SO}_{4}\right)_{2}\right]_{2} \cdot 8 \mathrm{H}_{2} \mathrm{O}$ [58]. As observed in $\mathrm{Rb}_{2}\left[\mathrm{UO}_{2}\left(\mathrm{SeO}_{4}\right)_{2}\left(\mathrm{H}_{2} \mathrm{O}\right)\right] \cdot 2 \mathrm{H}_{2} \mathrm{O}$, these minerals possess the same layer-chain configuration of $\left[\mathrm{UO}_{2}\left(\mathrm{SeO}_{4}\right)_{2}\left(\mathrm{H}_{2} \mathrm{O}\right)\right]^{2-}$ units extending in the layer direction. A further comparison can be found in the organically templated uranyl sulfate $\left[\mathrm{C}_{2} \mathrm{H}_{8} \mathrm{~N}_{2}\left[\left(\mathrm{UO}_{2}\right)\left(\mathrm{SeO}_{4}\right)_{2}\left(\mathrm{H}_{2} \mathrm{O}\right)\right]\right.$ [59] regarding the occurrence of interlinking $\left[\mathrm{UO}_{2}\left(\mathrm{SeO}_{4}\right)_{2}\left(\mathrm{H}_{2} \mathrm{O}\right)\right]^{2-}$ units. It was previously highlighted by Gurzhiy et al. [59] that such a configuration can lead to geometric isomerism occurring in the orientation of the sheets in these structures. It is noteworthy then that, through a variety of different synthesis/formation means, e.g., natural mineral formation, hydrothermal methods, or organic templating, that similar topological products can be obtained.

\subsection{Structural Studies (d) $\left(\mathrm{UO}_{2}\right)_{2}\left(\mathrm{HSeO}_{3}\right)_{2}\left(\mathrm{H}_{2} \mathrm{SeO}_{3}\right)_{2} \mathrm{Se}_{2} \mathrm{O}_{5}$}

$\left(\mathrm{UO}_{2}\right)_{2}\left(\mathrm{HSeO}_{3}\right)_{2}\left(\mathrm{H}_{2} \mathrm{SeO}_{3}\right)_{2} \mathrm{Se}_{2} \mathrm{O}_{5}$ was synthesized using a slow evaporation method under conditions of high acidity via selenic acid. Attempts were made to use synthesis conditions under more neutral $\mathrm{pH}$, however, only known monoselenite phases were obtained, i.e., failure to synthesize a diselenite product. $\left(\mathrm{UO}_{2}\right)_{2}\left(\mathrm{HSeO}_{3}\right)_{2}\left(\mathrm{H}_{2} \mathrm{SeO}_{3}\right)_{2} \mathrm{Se}_{2} \mathrm{O}_{5}$ was found to adopt an orthorhombic structure in space group $C m c 2_{1}$ where $a=28.4752(12) \AA$, $b=6.3410(3) \AA, c=10.8575(6) \AA$ and $V=1960.45(16) \AA^{3}$ using SC-XRD measurements. The structure consists of seven coordinate $\mathrm{U}$ atoms which form $\mathrm{UO}_{7}$ pentagonal bipyramid polyhedra that contain two short axial and collinear oxo $U=O$ bonds of 1.773(11) $\AA$ consistent with the uranyl group for hexavalent $\mathrm{U}$ in this coordination geometry. Surrounding the uranyl group equatorially in the $\mathrm{UO}_{7}$ polyhedra are five oxygen atoms corner-sharing provided by $\mathrm{HSeO}_{3}{ }^{-}, \mathrm{H}_{2} \mathrm{SeO}_{3}$ and diselenite $\mathrm{Se}_{2} \mathrm{O}_{5}{ }^{2-}$ ligands where the bond length ranges from 2.343(10) to 2.447(9) $\AA$ (Figure 4d). This coordination motif leads to the formation of discrete rings of $\left[\left(\mathrm{UO}_{2}\right)_{2}\left(\mathrm{HSeO}_{3}\right)_{2}\left(\mathrm{H}_{2} \mathrm{SeO}_{3}\right)_{2} \mathrm{Se}_{2} \mathrm{O}_{5}\right]_{2}$ (Figure $4 \mathrm{c}$ ) which combine to create the $0 \mathrm{D}$ structure. The rings consist of the $\mathrm{UO}_{7}$ polyhedra bridged in the [100] direction via Se2O52 - ligands which have Se-O bonds lengths ranging from 1.655(11) to 1.813(13) $\AA$ that are then connected in the [001] direction via HSeO3 - ligands of Se-O bond length 1.654(11) to 1.787(11) $\AA$. The vacant positions of the $\mathrm{UO}_{7}$ polyhedra are then coordinated via $\mathrm{H}_{2} \mathrm{SeO}_{3}$ ligands where the bond lengths of these range from 1.646(9) to 1.754(14) $\AA$. BVS calculations of the $\mathrm{O}$ positions in the $\mathrm{H}_{2} \mathrm{SeO}_{3}$ ligands for $\mathrm{O}(3)(\mathrm{Se}-\mathrm{O}(3)-\mathrm{H})$ and $\mathrm{O}(7)$ (Se-O(3)-H) produce respective values of 1.18 and 1.23 supporting the assignment and occurrence of $\mathrm{O}-\mathrm{H}$ groups. Further $\mathrm{BVS}$ calculations of $\mathrm{O}(2)$ position for in the $\mathrm{HSeO}_{3}{ }^{-}$ ligands produce a value of 1.07 supporting the assignment and occurrence of $\mathrm{O}-\mathrm{H}$ groups. 
BVS values of $6.05,3.96,4.08,4.05$, and 4.09 were determined for the U(1), Se(1), Se(2), Se(3) and $\mathrm{Se}(4)$ positions supporting the occurrence of hexavalent $\mathrm{U}$ and tetravalent $\mathrm{Se}$ in the structure of $\left(\mathrm{UO}_{2}\right)_{2}\left(\mathrm{SeO}_{3}\right)_{2}\left(\mathrm{H}_{2} \mathrm{SeO}_{3}\right)_{2} \mathrm{Se}_{2} \mathrm{O}_{5}$. Full BVS values are given in Table 5 .
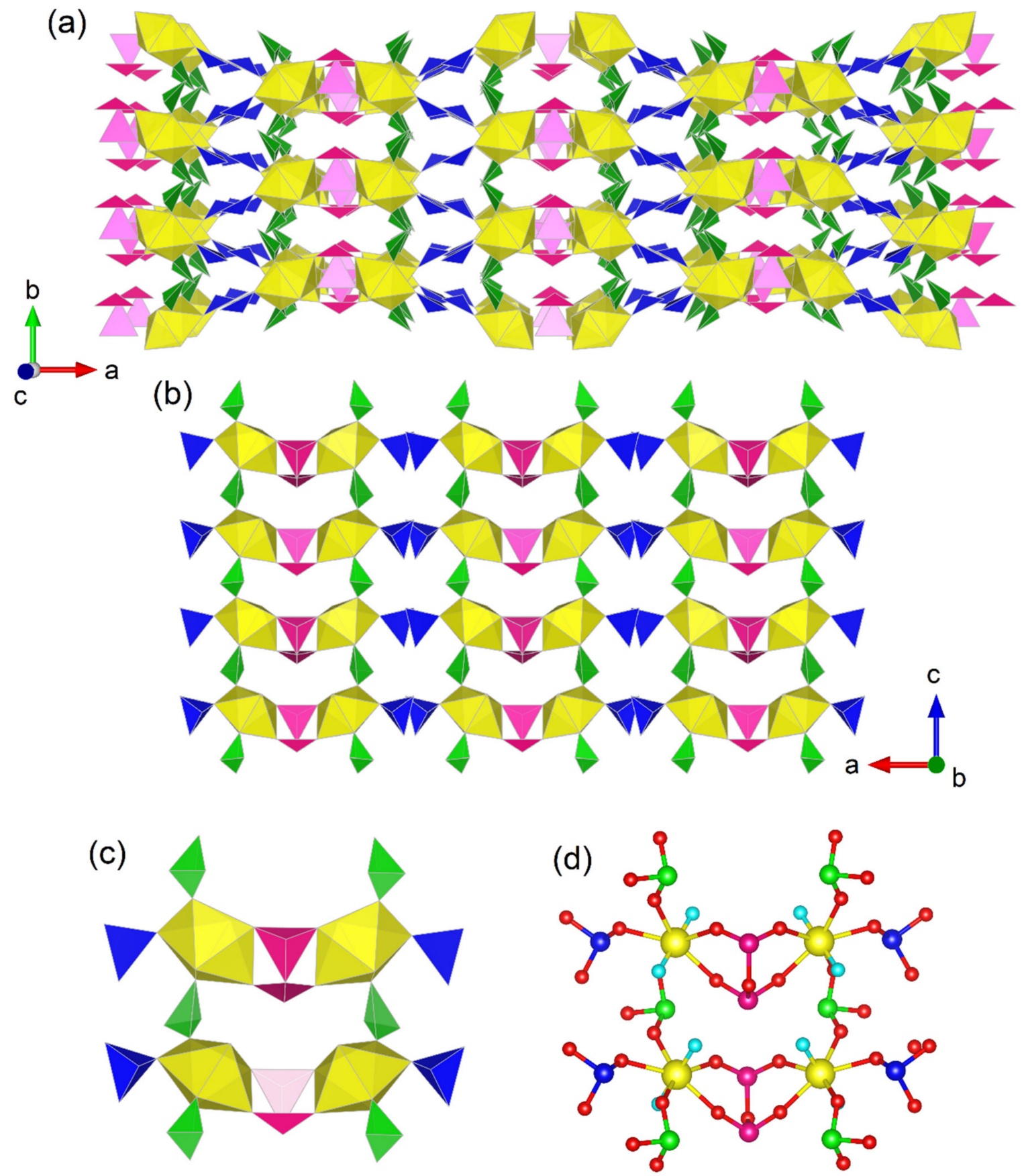

Figure 4. Structural representation of orthorhombic $\left(\mathrm{UO}_{2}\right)_{2}\left(\mathrm{HSeO}_{3}\right)_{2}\left(\mathrm{H}_{2} \mathrm{SeO}_{3}\right)_{2} \mathrm{Se}_{2} \mathrm{O}_{5}$ in space group Cmc $2_{1}$ (a) general representation, (b) in the [010] direction (c) highlighting the coordination motif of the $\left[\left(\mathrm{UO}_{2}\right)_{2}\left(\mathrm{HSeO}_{3}\right)_{2}\left(\mathrm{H}_{2} \mathrm{SeO}_{3}\right)_{2} \mathrm{Se}_{2} \mathrm{O}_{5}\right]_{2}$ rings and (d) the bonding motif of the rings. Note yellow polyhedra, green polyhedra, blue polyhedra, pink polyhedra, yellow spheres, red spheres, aqua blue spheres, green spheres, blue spheres and pink spheres respectively represent $\mathrm{UO}_{7}$, $\mathrm{HSeO}_{3}, \mathrm{H}_{2} \mathrm{SeO}_{3}, \mathrm{Se}_{2} \mathrm{O}_{5}, \mathrm{U}, \mathrm{O}$, uranyl $\mathrm{O}$, Se in $\mathrm{HSeO}_{3}$, Se in $\mathrm{H}_{2} \mathrm{SeO}_{3}$ and $\mathrm{Se}$ in $\mathrm{Se}_{2} \mathrm{O}_{5}$ units/atoms respectively. 
Table 5. BVS calculations for $\left(\mathrm{UO}_{2}\right)_{2}\left(\mathrm{HSeO}_{3}\right)_{2}\left(\mathrm{H}_{2} \mathrm{SeO}_{3}\right)_{2} \mathrm{Se}_{2} \mathrm{O}_{5}$.

\begin{tabular}{|c|c|c|c|c|c|c|}
\hline & $\mathbf{U}$ & $\operatorname{Se}(1)$ & $\operatorname{Se}(2)$ & $\mathrm{Se}(3)$ & $\operatorname{Se}(4)$ & $\Sigma$ \\
\hline O1 & 1.688 & & & & & 1.70 \\
\hline $\mathrm{O} 2$ & & & & 1.066 & & 1.07 \\
\hline $\mathrm{O} 3$ & & 1.167 & & & & 1.18 \\
\hline $\mathrm{O} 4$ & 0.455 & 1.560 & & & & 2.02 \\
\hline O5 & 0.550 & & & 1.453 & & 2.00 \\
\hline O6 & 1.705 & & & & & 1.71 \\
\hline O7 & & 1.230 & & & & 1.23 \\
\hline O8 & & & 1.03 & & 0.994 & 2.02 \\
\hline O9 & 0.557 & & & & $1.547^{x 2 \downarrow}$ & 2.10 \\
\hline $\mathrm{O} 10$ & 0.537 & & $1.53^{x 2 \downarrow}$ & & & 2.07 \\
\hline O11 & 0.561 & & & 1.527 & & 2.09 \\
\hline$\Sigma$ & 6.05 & 3.96 & 4.08 & 4.05 & 4.09 & \\
\hline
\end{tabular}

Besides $\left(\mathrm{UO}_{2}\right)_{2}\left(\mathrm{HSeO}_{3}\right)_{2}\left(\mathrm{H}_{2} \mathrm{SeO}_{3}\right)_{2} \mathrm{Se}_{2} \mathrm{O}_{5}$, the only reported uranyl, or indeed actinide, diselenite possessing compound was that of $\mathrm{UO}_{2} \mathrm{Se}_{2} \mathrm{O}_{5}$ [12]. $\mathrm{UO}_{2} \mathrm{Se}_{2} \mathrm{O}_{5}$ was originally synthesized using high temperature solid state methods involving excess $\mathrm{SeO}_{2}$ within a sealed tube. This is contrast to $\left(\mathrm{UO}_{2}\right)_{2}\left(\mathrm{HSeO}_{3}\right)_{2}\left(\mathrm{H}_{2} \mathrm{SeO}_{3}\right)_{2} \mathrm{Se}_{2} \mathrm{O}_{5}$ which was synthesized under slow evaporation conditions with excess acid. As previously described efforts were made to synthesis $\left(\mathrm{UO}_{2}\right)_{2}\left(\mathrm{HSeO}_{3}\right)_{2}\left(\mathrm{H}_{2} \mathrm{SeO}_{3}\right)_{2} \mathrm{Se}_{2} \mathrm{O}_{5}$ and /or diselenite variants using conditions of more moderate $\mathrm{pH}$ but this subsequently failed. Such an observation was consistent with the uranyl polyiodate UPI-1 where it was noted the synthesis was only possible under conditions of heighted acidity [14]. The occurrence of $\mathrm{HSeO}_{3}{ }^{-}$and $\mathrm{H}_{2} \mathrm{SeO}_{3}$ ligands in the structure of $\left(\mathrm{UO}_{2}\right)_{2}\left(\mathrm{HSeO}_{3}\right)_{2}\left(\mathrm{H}_{2} \mathrm{SeO}_{3}\right)_{2} \mathrm{Se}_{2} \mathrm{O}_{5}$ are indicative of the acidic synthesis conditions used and it is strongly suggested that they play a key role in structure formation. Extending to non-actinide variants, the occurrence of the diselenite group has also been observed in a number notable examples, including $\mathrm{Bi}_{3}\left(\mathrm{SeO}_{3}\right)_{3}\left(\mathrm{Se}_{2} \mathrm{O}_{5}\right) \mathrm{F}$, $\mathrm{Al}_{2}\left(\mathrm{Se}_{2} \mathrm{O}_{5}\right)_{3}, \mathrm{Ga}_{2}\left(\mathrm{Se}_{2} \mathrm{O}_{5}\right)_{3}$, and $\operatorname{In}_{2}\left(\mathrm{Se}_{2} \mathrm{O}_{5}\right)_{3}[13,60]$. These structures were found to exhibit superior SHG properties and were synthesized either using a sealed tube high temperature method $\left(\mathrm{Al}_{2}\left(\mathrm{Se}_{2} \mathrm{O}_{5}\right)_{3}, \mathrm{Ga}_{2}\left(\mathrm{Se}_{2} \mathrm{O}_{5}\right)_{3}\right.$ and $\left.\operatorname{In}_{2}\left(\mathrm{Se}_{2} \mathrm{O}_{5}\right)_{3}\right)$ or via a hydrothermal method involving highly acidic conditions $\left(\mathrm{Bi}_{3}\left(\mathrm{SeO}_{3}\right)_{3}\left(\mathrm{Se}_{2} \mathrm{O}_{5}\right) \mathrm{F}\right)$. Another notable synthesis was that of $\mathrm{Ca}_{2}\left(\mathrm{HSeO}_{3}\right)_{2}\left(\mathrm{Se}_{2} \mathrm{O}_{5}\right)$ which was achieved using a slow evaporation method utilizing selenic acid [61]. Consistent with the previous deductions of this investigations, it follows that either high temperature mildly reducing or acidic conditions are necessary to drive the polymerisation of selenite units for the formation of diselenite moieties.

\subsection{Synthesis and Structural Trends in Uranyl Selenites/Selenates}

A comprehension study on the crystal chemistry of natural and synthetic uranyl selenites and some selenates was recently completed by Gurzhiy et al. [52]. In light of this, we will only briefly discuss the crystal chemistry of uranyl selenites and selenates in the context of the novel phases uncovered in this work and direct the reader to Gurzhiy et al. [52] for broader background information. It was highlighted by Gurzhiy et al. [52] that the structural complexity of natural vs. synthetic uranyl selenites is comparatively higher for the former case of structures. Gurzhiy et al. [52] rationalised these observations against the preference for natural-born architectures to exist rather than the synthetic counterparts. Although, as described by Frost et al. [62] in examining the natural uranyl sulfate mineral zippeite, $\mathrm{K}_{2}\left[\left(\mathrm{UO}_{2}\right)_{6}\left(\mathrm{SO}_{4}\right)_{3} \mathrm{O}(\mathrm{OH})_{6}\right] \cdot 8 \mathrm{H}_{2} \mathrm{O}$, natural conditions often involve a higher temperature gradient compared to that of the synthetic regarding compounds synthesized using hydrothermal methods. Accordingly, high temperature synthesis conditions typically result in higher symmetry structure formation, which as a method for uranyl selenite and selenate synthesis is underutilized typically due to the volatility of selenium and the associated difficulty. However, such synthesis conditions were used to synthesize, prior to this investigation, the only reported diselenite $\mathrm{UO}_{2} \mathrm{Se}_{2} \mathrm{O}_{5}$ [12] as well 
as notable non-actinide diselenite variants [13,60,61], as previously described. Although the mechanism for selenite polymerisation in $\mathrm{UO}_{2} \mathrm{Se}_{2} \mathrm{O}_{5}$ is not clear it is speculated to be related to the combination of high temperature and the somewhat reducing conditions of a sealed tube. Nevertheless, as highlighted and argued in this investigation, $\mathrm{pH}$ control can act as promoter of selenite polymerisation in the case of slow evaporation acid assisted $\left(\mathrm{UO}_{2}\right)_{2}\left(\mathrm{HSeO}_{3}\right)_{2}\left(\mathrm{H}_{2} \mathrm{SeO}_{3}\right)_{2} \mathrm{Se}_{2} \mathrm{O}_{5}$ synthesis.

The role of acidity during synthesis, as described previously, has been noted in several recent studies to act as a key determinant in controlling such chemical properties as structural motif, isomerism and also redox processes [17-20,22,23]. Nazarchuk et al. [22] described that, during the evaporation of acidic solutions, the successive reduction in $\mathrm{pH}$ accompanied by a loss of solution resulted in distinctive organically templated uranyl sulfate structures forming which were structural dependent and proportional to the $\mathrm{pH}$ at which crystallisation occurs. In the present study, initial solution $\mathrm{pH}$ conditions were targeted at $<1$, such that, at crystallisation and near complete evaporation of solution, the structures formed were at the extremity of acidity content. Similar extreme $\mathrm{pH} /$ acidity conditions and methodologies were utilized in the studies of variable geometric isomerism in uranyl and neptunyl nitrates [17] and also in UPI-1, the first actinide polyiodate [14]. Contrasting the systematic study of Nazarchuk et al. [22] with that of the aforementioned and present studies suggests greater control of structure formation can be obtained through more incremental $\mathrm{pH}$ steps and this may allow other structure derivatives to be obtained, e.g., via $\mathrm{pH}$ controlled addition or exclusion of acid or water units in structures.

A common feature of the present study has been the structural similarities of the uranyl selenates $\mathrm{Rb}_{2}\left[\left(\mathrm{UO}_{2}\right)_{2}\left(\mathrm{SeO}_{4}\right)_{3}\right]$ and $\mathrm{Rb}_{2}\left[\mathrm{UO}_{2}\left(\mathrm{SeO}_{4}\right)_{2}\left(\mathrm{H}_{2} \mathrm{O}\right)\right] \cdot 2 \mathrm{H}_{2} \mathrm{O}$ with that of sulfate and chromate analogues. As described, the corrugation of the layers observed in $\mathrm{Rb}_{2}\left[\left(\mathrm{UO}_{2}\right)_{2}\left(\mathrm{SeO}_{4}\right)_{3}\right]$ can be similarly found in $\mathrm{Cs}_{2}\left[\left(\mathrm{UO}_{2}\right)_{2}\left(\mathrm{CrO}_{4}\right)_{3}\right]$ [19] and $[\mathrm{pyH}]_{2}\left[\left(\mathrm{UO}_{2}\right)_{2}\left(\mathrm{SO}_{4}\right)_{3}\right]$ [22], which is suspected to be related to the unideal coordination of $\mathrm{SeO}_{4} / \mathrm{CrO}_{4} / \mathrm{SO}_{4}$ ligands in the structure leading to similar distortions observed. However, in the case of $\mathrm{Rb}_{2}\left[\mathrm{UO}_{2}\left(\mathrm{SeO}_{4}\right)_{2}\left(\mathrm{H}_{2} \mathrm{O}\right)\right] \cdot 2 \mathrm{H}_{2} \mathrm{O}$, the layer-chain configuration of the $\left[\mathrm{UO}_{2}\left(\mathrm{SeO}_{4}\right)_{2}\left(\mathrm{H}_{2} \mathrm{O}\right)\right]^{2-}$ units can be readily observed in the natural sulfate analogues of bobcookite, $\mathrm{NaAl}\left(\mathrm{UO}_{2}\right)_{2}\left(\mathrm{SO}_{4}\right)_{4} \cdot 18 \mathrm{H}_{2} \mathrm{O}$ [57], and svornostite, $\mathrm{K}_{2} \mathrm{Mg}\left[\left(\mathrm{UO}_{2}\right)\left(\mathrm{SO}_{4}\right)_{2}\right]_{2} \cdot 8 \mathrm{H}_{2} \mathrm{O}$ [58]. The ability for the exchangeability of the different structural-chemical analogues arises due to the similar sizes of the selenate, sulfate, and chromate ions. Consequently, utilising synthetic techniques, such as acidic hydrothermal/slow evaporation conditions used in the present study, developed for a specific system, such as selenate, these can be readily transferred to sulfate or chromate with either similar or unexpected success in the synthesis. Naturally, variability in redox chemistry can limit transferability, e.g., the ion polymerisation process. However, other structural effects, such as degree of hydration and distortion mechanisms, can be readily examined, controlled, and contrasted against the three different systems.

In the present study and supported by observations in recent investigations [17-20,22,23], the use of low $\mathrm{pH}$ conditions acts as a facile path towards novel structure generation and obtaining topology architectures that would otherwise require more intricate synthesis methods, such as the use of organic templating methods. Consequently, it is suggested then, from the observations in this investigation, that the use and presence of acid during synthesis provides a facile pathway to acquiring uranyl selenite/selenate structures with functional groups or topologies that are either novel or require more intricate methods.

\section{Conclusions}

The novel uranyl selenites and selenates $\mathrm{Rb}_{2}\left[\left(\mathrm{UO}_{2}\right)_{2}\left(\mathrm{SeO}_{4}\right)_{3}\right], \mathrm{Rb}_{2}\left[\left(\mathrm{UO}_{2}\right)_{3}\left(\mathrm{SeO}_{3}\right)_{2} \mathrm{O}_{2}\right]$, $\mathrm{Rb}_{2}\left[\mathrm{UO}_{2}\left(\mathrm{SeO}_{4}\right)_{2}\left(\mathrm{H}_{2} \mathrm{O}\right)\right] \cdot 2 \mathrm{H}_{2} \mathrm{O}$, and $\left(\mathrm{UO}_{2}\right)_{2}\left(\mathrm{HSeO}_{3}\right)_{2}\left(\mathrm{H}_{2} \mathrm{SeO}_{3}\right)_{2} \mathrm{Se}_{2} \mathrm{O}_{5}$ have been synthesized using either slow evaporation or hydrothermal methods, both involving extensive acid addition, and their structures characterized using single crystal X-ray diffraction. Prior to this investigation, only one uranyl diselenite was known [12]. Accordingly, the synthesis 
herein of $\left(\mathrm{UO}_{2}\right)_{2}\left(\mathrm{HSeO}_{3}\right)_{2}\left(\mathrm{H}_{2} \mathrm{SeO}_{3}\right)_{2} \mathrm{Se}_{2} \mathrm{O}_{5}$ utilizing acidic conditions provides only the second such example and the first from slow evaporation synthesis. Key to this and the other novel compounds described is the application of extensive acid during synthesis, which is argued to act as a novel and facile method towards acquiring structures and topologies that would otherwise require more intricate methods such as organic templating. With the consideration of recent similar studies $[14,17]$, this investigation points towards the pertinence of acid and $\mathrm{pH}$ control in the synthesis of novel uranyl selenite and selenate compositions and structures, particularly those that that may possess salient SHG properties.

Author Contributions: Conceptualization, G.L.M., P.K., E.M.L., and E.V.A.; methodology, G.L.M. and E.V.A.; validation, all authors.; formal analysis, G.L.M. and E.V.A.; investigation, all authors; resources, E.V.A. and P.K.; writing—original draft preparation, G.L.M. and E.V.A.; writing-review and editing, all authors; visualization, G.L.M. and E.V.A.; supervision, G.L.M. and E.V.A.; project administration, E.V.A.; funding acquisition, E.V.A. All authors have read and agreed to the published version of the manuscript.

Funding: The work has been supported by the Deutsche Forschungsgemeinschaft (DFG) grant AL1527/3-1.

Data Availability Statement: The structures obtained in this investigation were deposited into the Cambridge Crystallographic Data Centre (CCDC) under the numbers 2101372, 2094250, 2094251, and 2094249 for $\mathrm{Rb}_{2}\left[\left(\mathrm{UO}_{2}\right)_{2}\left(\mathrm{SeO}_{4}\right)_{3}\right], \mathrm{Rb}_{2}\left[\mathrm{UO}_{2}\left(\mathrm{SeO}_{4}\right)_{2}\left(\mathrm{H}_{2} \mathrm{O}\right)\right] \cdot 2 \mathrm{H}_{2} \mathrm{O}, \mathrm{Rb}_{2}\left[\left(\mathrm{UO}_{2}\right)_{3}\left(\mathrm{SeO}_{3}\right)_{2} \mathrm{O}_{2}\right]$, and $\left(\mathrm{UO}_{2}\right)_{2}\left(\mathrm{HSeO}_{3}\right)\left(\mathrm{H}_{2} \mathrm{SeO}_{3}\right)_{2} \mathrm{Se}_{2} \mathrm{O}_{5}$, respectively.

Conflicts of Interest: No conflicts of interest.

\section{References}

1. Guo, S.-P.; Chi, Y.; Guo, G.-C. Recent achievements on middle and far-infrared second-order nonlinear optical materials. Coord. Chem. Rev. 2017, 335, 44-57. [CrossRef]

2. Abudurusuli, A.; Li, J.; Pan, S. A review on the recently developed promising infrared nonlinear optical materials. Dalton Trans. 2021, 50, 3155-3160. [CrossRef]

3. Dineva, P.; Gross, D.; Müller, R.; Rangelov, T. Piezoelectric materials. In Dynamic Fracture of Piezoelectric Materials; Springer: Berlin, Germany, 2014; pp. 7-32.

4. $\mathrm{Xu}, \mathrm{Y} .>$ Ferroelectric Materials and Their Applications; Elsevier: Amsterdam, The Netherlands, 2013.

5. Lin, J.; Liu, Q.; Yue, Z.; Diefenbach, K.; Cheng, L.; Lin, Y.; Wang, J.-Q. Expansion of the structural diversity of f-element bearing molybdate iodates: Synthesis, structures, and optical properties. Dalton Trans. 2019, 48, 4823-4829. [CrossRef]

6. Qie, M.; Lin, J.; Kong, F.; Silver, M.A.; Yue, Z.; Wang, X.; Zhang, L.; Bao, H.; Albrecht-Schmitt, T.E.; Wang, J.-Q. A Large Family of Centrosymmetric and Chiral f-Element-Bearing Iodate Selenates Exhibiting Coordination Number and Dimensional Reductions. Inorg. Chem. 2018, 57, 1676-1683. [CrossRef]

7. Wang, Y.; Duan, T.; Weng, Z.; Ling, J.; Yin, X.; Chen, L.; Sheng, D.; Diwu, J.; Chai, Z.; Liu, N.; et al. Mild Periodic Acid Flux and Hydrothermal Methods for the Synthesis of Crystalline f-Element-Bearing Iodate Compounds. Inorg. Chem. 2017, 56, 13041-13050. [CrossRef]

8. Wang, Y.; Yin, X.; Liu, W.; Xie, J.; Chen, J.; Silver, M.A.; Sheng, D.; Chen, L.; Diwu, J.; Liu, N.; et al. Emergence of Uranium as a Distinct Metal Center for Building Intrinsic X-ray Scintillators. Angew. Chem. Int. Ed. 2018, 57, 7883-7887. [CrossRef] [PubMed]

9. $\mathrm{Xu}, \mathrm{X}$; $\mathrm{Hu}, \mathrm{C} .-\mathrm{L} . ; \mathrm{Li}, \mathrm{B} .-\mathrm{X} . ;$ Yang, B.-P.; Mao, J.-G. $\alpha-\mathrm{AgI}_{3} \mathrm{O}_{8}$ and $\beta-\mathrm{AgI}_{3} \mathrm{O}_{8}$ with large $\mathrm{SHG}$ responses: Polymerization of $\mathrm{IO}_{3}$ groups into the $\mathrm{I}_{3} \mathrm{O}_{8}$ polyiodate anion. Chem. Mater. 2014, 26, 3219-3230. [CrossRef]

10. Phanon, D.; Gautier-Luneau, I. Promising material for infrared nonlinear optics: $\mathrm{NaI}_{3} \mathrm{O}_{8}$ salt containing an octaoxotriiodate (V) anion formed from condensation of $\left[\mathrm{IO}_{3}\right]^{-}$ions. Angew. Chem. Int. Ed. 2007, 46, 8488-8491. [CrossRef] [PubMed]

11. Chen, J.; Hu, C.-L.; Mao, F.-F.; Yang, B.-P.; Zhang, X.-H.; Mao, J.-G. $\mathrm{REI}_{5} \mathrm{O}_{14}$ (RE=Y and Gd): Promising SHG Materials Featuring the Semicircle-Shaped $\mathrm{I}_{5} \mathrm{O}_{14}{ }^{3-}$ Polyiodate Anion. Angew. Chem. Int. Ed. 2019, 58, 11666-11669. [CrossRef] [PubMed]

12. Trombe, J.; Gleizes, A.; Galy, J. Structure of a uranyl diselenite, UO2Se2O5. Acta Crystallogr. Sect. C Cryst. Struct. Commun. 1985, 41, 1571-1573. [CrossRef]

13. Ok, K.M.; Halasyamani, P.S. New selenites: Syntheses, structures, and characterization of centrosymmetric $\mathrm{Al}_{2}\left(\mathrm{Se}_{2} \mathrm{O}_{5}\right)_{3}$ and $\mathrm{Ga}_{2}\left(\mathrm{Se}_{2} \mathrm{O}_{5}\right)_{3}$ and non-centrosymmetric $\mathrm{In}_{2}\left(\mathrm{Se}_{2} \mathrm{O}_{5}\right)_{3}$. Chem. Mater. 2002, 14, 2360-2364. [CrossRef]

14. Murphy, G.L.; Wang, Y.; Kegler, P.; Wang, Y.; Wang, S.; Alekseev, E.V. The first actinide polyiodate: A complex multifunctional compound with promising X-ray luminescence properties and proton conductivity. Chem. Commun. 2021, 57, 496-499. [CrossRef]

15. Mao, F.-F.; Hu, C.-L.; Chen, J.; Wu, B.-L.; Mao, J.-G. $\mathrm{HBa}_{2 .}{ }_{5}\left(\mathrm{IO}_{3}\right)_{6}\left(\mathrm{I}_{2} \mathrm{O}_{5}\right)$ and $\mathrm{HBa}\left(\mathrm{IO}_{3}\right)\left(\mathrm{I}_{4} \mathrm{O}_{11}\right)$ : Explorations of Second-Order Nonlinear Optical Materials in the Alkali-Earth Polyiodate System. Inorg. Chem. 2019, 58, 3982-3989. [CrossRef]

16. Abudouwufu, T.; Zhang, M.; Cheng, S.; Zeng, H.; Yang, Z.; Pan, S. $\mathrm{K}_{2} \mathrm{Na}\left(\mathrm{IO}_{3}\right)_{2}\left(\mathrm{I}_{3} \mathrm{O}_{8}\right)$ with Strong Second Harmonic Generation Response Activated by Two Types of Isolated Iodate Anions. Chem. Mater. 2020, 32, 3608-3614. [CrossRef] 
17. Murphy, G.L.; Langer, E.M.; Walter, O.; Wang, Y.; Wang, S.; Alekseev, E.V. Insights into the Structural Chemistry of Anhydrous and Hydrous Hexavalent Uranium and Neptunium Dinitrato, Trinitrato, and Tetranitrato Complexes. Inorg. Chem. 2020, 59, 7204-7215. [CrossRef]

18. Gurzhiy, V.V.; Tyumentseva, O.S.; Kornyakov, I.V. Uranyl Nitrates: By-Products of the Synthetic Experiments or Key Indicators of the Reaction Progress? Crystals 2020, 10, 1122. [CrossRef]

19. Siidra, O.I.; Nazarchuk, E.V.; Kayukov, R.A.; Bubnova, R.S.; Krivovichev, S.V. CrVI $\rightarrow$ CrV Transition in Uranyl Chromium Compounds: Synthesis and High-temperature X-ray Diffraction Study of $\mathrm{Cs}_{2}\left[\left(\mathrm{UO}_{2}\right)_{2}\left(\mathrm{CrO}_{4}\right)_{3}\right]$. Z. Anorg. Allg. Chem. 2013, 639, 2302-2306. [CrossRef]

20. Nazarchuk, E.V.; Siidra, O.I.; Charkin, D.O.; Kalmykov, S.N.; Kotova, E.L. Effect of solution acidity on the crystallization of polychromates in uranyl-bearing systems: Synthesis and crystal structures of $\mathrm{Rb}_{2}\left[\left(\mathrm{UO}_{2}\right)\left(\mathrm{Cr}_{2} \mathrm{O}_{7}\right)\left(\mathrm{NO}_{3}\right)_{2}\right]$ and two new polymorphs of $\mathrm{Rb}_{2} \mathrm{Cr}_{3} \mathrm{O}_{10}$. Z. Krist. Cryst. Mater. 2021, 236, 11-21. [CrossRef]

21. Nazarchuk, E.V.; Ikhalaynen, Y.A.; Charkin, D.O.; Siidra, O.I.; Petrov, V.G.; Kalmykov, S.N.; Borisov, A.S. Effect of solution acidity on the structure of amino acid-bearing uranyl compounds. Radiochim. Acta 2019, 107, 311-325. [CrossRef]

22. Nazarchuk, E.V.; Charkin, D.O.; Siidra, O.I. Successive crystallization of organically templated uranyl sulfates: Synthesis and crystal structures of $[\mathrm{pyH}]\left(\mathrm{H}_{3} \mathrm{O}\right)\left[\left(\mathrm{UO}_{2}\right) 3\left(\mathrm{SO}_{4}\right)_{4}\left(\mathrm{H}_{2} \mathrm{O}\right)_{2}\right],[\mathrm{pyH}] 2\left[\left(\mathrm{UO}_{2}\right)_{6}\left(\mathrm{SO}_{4}\right)_{7}\left(\mathrm{H}_{2} \mathrm{O}\right)\right]$, and $[\mathrm{pyH}]_{2}\left[\left(\mathrm{UO}_{2}\right)_{2}\left(\mathrm{SO}_{4}\right)_{3}\right]$. ChemEngineering 2021, 5, 5. [CrossRef]

23. Langer, E.M.; Walter, O.; Colle, J.-Y.; Bosbach, D.; Alekseev, E.V. Unexpected Behavior of Np in Oxo-selenate/Oxo-selenite Systems. Inorg. Chem. 2018, 57, 1604-1613. [CrossRef]

24. Kleykamp, H. The Chemical State of the Fission-Products in Oxide Fuels. J. Nucl. Mater. 1985, 131, 221-246. [CrossRef]

25. Kleykamp, H. The Chemical-State of Fission-Products in Oxide Fuels at different Stages of the Nuclear-Fuel Cycle. Nucl. Technol. 1988, 80, 412-422. [CrossRef]

26. Murphy, G.; Kennedy, B.J.; Johannessen, B.; Kimpton, J.A.; Avdeev, M.; Griffith, C.S.; Thorogood, G.J.; Zhang, Z.M. Structural studies of the rhombohedral and orthorhombic monouranates: $\mathrm{CaUO}_{4}$, alpha-SrUO 4 , beta-SrUO 4 and $\mathrm{BaUO}_{4}$. J. Solid State Chem. 2016, 237, 86-92. [CrossRef]

27. Hao, Y.; Klepov, V.V.; Murphy, G.L.; Modolo, G.; Bosbach, D.; Albrecht-Schmitt, T.E.; Kennedy, B.J.; Wang, S.; Alekseev, E.V. Influence of Synthetic Conditions on Chemistry and Structural Properties of Alkaline Earth Uranyl Borates. Cryst. Growth Des. 2016, 16, 5923-5931. [CrossRef]

28. Murphy, G.L.; Kennedy, B.J.; Kimpton, J.A.; Gu, Q.; Johannessen, B.; Beridze, G.; Kowalski, P.M.; Bosbach, D.; Avdeev, M.; Zhang, Z. Nonstoichiometry in Strontium Uranium Oxide: Understanding the Rhombohedral-Orthorhombic Transition in SrUO $_{4}$. Inorg. Chem. 2016, 55, 9329-9334. [CrossRef]

29. Hao, Y.; Murphy, G.L.; Bosbach, D.; Modolo, G.; Albrecht-Schmitt, T.E.; Alekseev, E.V. Porous Uranyl Borophosphates with Unique Three-Dimensional Open-Framework Structures. Inorg. Chem. 2017, 56, 9311-9320. [CrossRef] [PubMed]

30. Murphy, G.L.; Kegler, P.; Klinkenberg, M.; Wang, S.; Alekseev, E.V. Extreme condition high temperature and high pressure studies of the K-U-Mo-O system. Dalton Trans. 2020, 49, 15843-15853. [CrossRef]

31. Murphy, G.L.; Zhang, Z.; Tesch, R.; Kowalski, P.M.; Avdeev, M.; Kuo, E.Y.; Gregg, D.J.; Kegler, P.; Alekseev, E.V.; Kennedy, B.J. Tilting and Distortion in Rutile-Related Mixed Metal Ternary Uranium Oxides: A Structural, Spectroscopic, and Theoretical Investigation. Inorg. Chem. 2021, 60, 2246-2260. [CrossRef]

32. Bean, A.C.; Campana, C.F.; Kwon, O.; Albrecht-Schmitt, T.E. A New Oxoanion: $\left[\mathrm{IO}_{4}\right]^{3-}$ Containing I(V) with a Stereochemically Active Lone-Pair in the Silver Uranyl Iodate Tetraoxoiodate(V), $\mathrm{Ag}_{4}\left(\mathrm{UO}_{2}\right)_{4}\left(\mathrm{IO}_{3}\right)_{2}\left(\mathrm{IO}_{4}\right)_{2} \mathrm{O}_{2}$. J. Am. Chem. Soc. 2001, 123, 8806-8810. [CrossRef]

33. Bean, A.C.; Peper, S.M.; Albrecht-Schmitt, T.E. Structural Relationships, Interconversion, and Optical Properties of the Uranyl Iodates, $\mathrm{UO}_{2}\left(\mathrm{IO}_{3}\right)_{2}$ and $\mathrm{UO}_{2}\left(\mathrm{IO}_{3}\right)_{2}\left(\mathrm{H}_{2} \mathrm{O}\right)$ : A Comparison of Reactions under Mild and Supercritical Conditions. Chem. Mater. 2001, 13, 1266-1272. [CrossRef]

34. Liu, H.; Qin, H.; Shen, N.; Yan, S.; Wang, Y.; Yin, X.; Chen, X.; Zhang, C.; Dai, X.; Zhou, R.; et al. Emergence of a Radical-Stabilizing Metal-Organic Framework as a Radio-photoluminescence Dosimeter. Angew. Chem. Int. Ed. 2020, 57. [CrossRef]

35. Gui, D.; Duan, W.; Shu, J.; Zhai, F.; Wang, N.; Wang, X.; Xie, J.; Li, H.; Chen, L.; Diwu, J.; et al. Persistent Superprotonic Conductivity in the Order of $10-1 \mathrm{~S} \cdot \mathrm{cm}-1$ Achieved Through Thermally Induced Structural Transformation of a Uranyl Coordination Polymer. CCS Chem. 2019, 1, 197-206. [CrossRef]

36. Wang, Y.; Yin, X.; Chen, J.; Wang, Y.; Chai, Z.; Wang, S. Gleaming Uranium: An Emerging Emitter for Building X-ray Scintillators. Chem. Eur. J. 2020, 26, 1900-1905. [CrossRef]

37. Murphy, G.L.; Kegler, P.; Zhang, Y.; Zhang, Z.; Alekseev, E.V.; de Jonge, M.D.; Kennedy, B.J. High-pressure synthesis, structural, and spectroscopic studies of the Ni-U-O system. Inorg. Chem. 2018, 57, 13847-13858. [CrossRef]

38. Murphy, G.L.; Wang, C.H.; Zhang, Z.M.; Kowalski, P.M.; Beridze, G.; Avdeev, M.; Muransky, O.; Brand, H.E.A.; Gu, Q.F.; Kennedy, B.J. Controlling Oxygen Defect Formation and Its Effect on Reversible Symmetry Lowering and Disorder-to-Order Phase Transformations in Nonstoichiometric Ternary Uranium Oxides. Inorg. Chem. 2019, 58, 6143-6154. [CrossRef]

39. Sheldrick, G. A short history of SHELX. Acta Crystallogr. Sect. A 2008, 64, 112-122. [CrossRef]

40. Spek, A. Single-crystal structure validation with the program PLATON. J. Appl. Crystallogr. 2003, 36, 7-13. [CrossRef]

41. Burns, P.C.; Ewing, R.C.; Hawthorne, F.C. The crystal chemistry of hexavalent uranium: Polyhedron geometries, bond-valence parameters, and polymerization of polyhedra. Can. Mineral. 1997, 35, 1551-1570. 
42. Brese, N.E.; O'Keeffe, M. Bond-valence parameters for solids. Acta Crystallogr. Sect. B 1991, 47, 192-197. [CrossRef]

43. Murphy, G.L.; Zhang, Z.; Kennedy, B.J. The Solid-State Uranium Chemistry of Ternary AUO4 Oxides: A Review. In Complex Oxides: An Introduction; World Scientific: Singapore, 2019; pp. 103-130.

44. Xiao, B.; Kegler, P.; Gesing, T.M.; Robben, L.; Blanca-Romero, A.; Kowalski, P.M.; Li, Y.; Klepov, V.; Bosbach, D.; Alekseev, E.V. Giant Volume Change and Topological Gaps in Temperature- and Pressure-Induced Phase Transitions: Experimental and Computational Study of $\mathrm{ThMo}_{2} \mathrm{O}_{8}$. Chem. Eur. J. 2016, 22, 946-958. [CrossRef] [PubMed]

45. Ghazisaeed, S.; Kiefer, B.; Plášil, J. Revealing hydrogen atoms in a highly-absorbing material: An X-ray diffraction study and Torque method calculations for lead-uranyl-oxide mineral curite. RSC Adv. 2019, 9, 10058-10063. [CrossRef]

46. Plášil, J.; Veselovský, F.; Hloušek, J.; Škoda, R.; Novák, M.; Sejkora, J.; Čejka, J.; Škácha, P.; Kasatkin, A.V. Mathesiusite, $\mathrm{K}_{5}\left(\mathrm{UO}_{2}\right)_{4}\left(\mathrm{SO}_{4}\right)_{4}\left(\mathrm{VO}_{5}\right)\left(\mathrm{H}_{2} \mathrm{O}\right)_{4}$, a new uranyl vanadate-sulfate from Jáchymov, Czech Republic. Am. Miner. 2014, 99, 625-632. [CrossRef]

47. Ross, M.; Evans, H.T. The crystal structure of cesium biuranyl trisulphate, $\mathrm{Cs}_{2}\left(\mathrm{UO}_{2}\right)_{2}\left(\mathrm{SO}_{4}\right)_{3}$. J. Inorg. Nucl. Chem. 1960, 15, 338-351. [CrossRef]

48. Krivovichev, S.V.; Cahill, C.L.; Burns, P.C. Syntheses and Crystal Structures of Two Topologically Related Modifications of $\mathrm{Cs}_{2}\left[\left(\mathrm{UO}_{2}\right)_{2}\left(\mathrm{MoO}_{4}\right)_{3}\right]$. Inorg. Chem. 2002, 41, 34-39. [CrossRef]

49. Almond, P.M.; Albrecht-Schmitt, T.E. Hydrothermal synthesis and crystal chemistry of the new strontium uranyl selenites, $\mathrm{Sr}\left[\left(\mathrm{UO}_{2}\right)_{3}\left(\mathrm{SeO}_{3}\right)_{2} \mathrm{O}_{2}\right] \cdot 4 \mathrm{H}_{2} \mathrm{O}$ and $\mathrm{Sr}\left[\mathrm{UO}_{2}\left(\mathrm{SeO}_{3}\right)_{2}\right]$. Am. Miner. 2004, 89, 976-980. [CrossRef]

50. Wylie, E.M.; Burns, P.C. Crystal structures of six new uranyl selenate and selenite compounds and their relationship with uranyl mineral structures. Can. Miner. 2012, 50, 147-157. [CrossRef]

51. Cooper, M.A.; Hawthorne, F.C. The crystal structure of guilleminite, a hydrated Ba-U-Se sheet structure. Can. Miner. 1995, 33, 1103-1109.

52. Gurzhiy, V.V.; Kuporev, I.V.; Kovrugin, V.M.; Murashko, M.N.; Kasatkin, A.V.; Plášil, J. Crystal Chemistry and Structural Complexity of Natural and Synthetic Uranyl Selenites. Crystals 2019, 9, 639. [CrossRef]

53. Cooper, M.A.; Hawthorne, F.C. Structure topology and hydrogen bonding in marthozite, $\mathrm{Cu}^{2+}\left[\left(\mathrm{UO}_{2}\right)_{3}\left(\mathrm{SeO}_{3}\right)_{2} \mathrm{O}_{2}\right]\left(\mathrm{H}_{2} \mathrm{O}\right)_{8}$, a comparison with guilleminite, $\mathrm{Ba}\left[\left(\mathrm{UO}_{2}\right)_{3}\left(\mathrm{SeO}_{3}\right)_{2} \mathrm{O}_{2}\right]\left(\mathrm{H}_{2} \mathrm{O}\right)_{3}$. Can. Miner. 2001, 39, 797-807. [CrossRef]

54. Krivovichev, S.V.; Kahlenberg, V. Structural Diversity of Sheets in Rubidium Uranyl Oxoselenates: Synthesis and Crystal Structures of $\mathrm{Rb}_{2}\left[\left(\mathrm{UO}_{2}\right)\left(\mathrm{SeO}_{4}\right)_{2}\left(\mathrm{H}_{2} \mathrm{O}\right)\right]\left(\mathrm{H}_{2} \mathrm{O}\right), \mathrm{Rb}_{2}\left[\left(\mathrm{UO}_{2}\right)_{2}\left(\mathrm{SeO}_{4}\right)_{3}\left(\mathrm{H}_{2} \mathrm{O}\right)_{2}\right]\left(\mathrm{H}_{2} \mathrm{O}\right)_{4}$, and $\mathrm{Rb}_{4}\left[\left(\mathrm{UO}_{2}\right)_{3}\left(\mathrm{SeO}_{4}\right)_{5}\left(\mathrm{H}_{2} \mathrm{O}\right)\right]$. Z. Anorg. Allg. Chem. 2005, 631, 739-744. [CrossRef]

55. Serezhkin, V.N.; Verevkin, A.V.; Smirnov, O.; PlakhtjĐ, V. Neutron diffraction study of $\mathrm{Rb}_{2} \mathrm{UO}_{2}\left(\mathrm{SeO}_{4}\right) 2 \cdot 2 \mathrm{D}_{2} \mathrm{O}$. Russ. J. Inorg. Chem. 2010, 55, 1600-1606. [CrossRef]

56. Jin, G.B.; Ling, J.; Estes, S.L.; Skanthakumar, S.; Soderholm, L. Influence of Countercation Hydration Enthalpies on the Formation of Molecular Complexes: A Thorium-Nitrate Example. J. Am. Chem. Soc. 2017, 139, 18003-18008. [CrossRef] [PubMed]

57. Kampf, A.R.; Plášil, J.; Kasatkin, A.V.; $\quad$ Marty, J. Bobcookite, $\mathrm{NaAl}\left(\mathrm{UO}_{2}\right)_{2}\left(\mathrm{SO}_{4}\right)_{4} \cdot 18 \mathrm{H}_{2} \mathrm{O}$ and wetherillite, $\mathrm{Na}_{2} \mathrm{Mg}\left(\mathrm{UO}_{2}\right)_{2}\left(\mathrm{SO}_{4}\right)_{4} \cdot 18 \mathrm{H}_{2} \mathrm{O}$, two new uranyl sulfate minerals from the Blue Lizard mine, San Juan County, Utah, USA. Mineral. Mag. 2015, 79, 695-714. [CrossRef]

58. Plasil, J.; Hlousek, J.; Kasatkin, A.V.; Novak, M.; Cejka, J.; Lapcak, L. Svornostite, $\mathrm{K}_{2} \mathrm{Mg}\left[\left(\mathrm{UO}_{2}\right)\left(\mathrm{SO}_{4}\right)_{2}\right]_{2} \cdot 8 \mathrm{H}_{2} \mathrm{O}$, a new uranyl sulfate mineral from Jachymov, Czech Republic. J. Geosci. 2015, 60, 113-121. [CrossRef]

59. Gurzhiy, V.V.; Kovrugin, V.M.; Tyumentseva, O.S.; Mikhaylenko, P.A.; Krivovichev, S.V.; Tananaev, I.G. Topologically and geometrically flexible structural units in seven new organically templated uranyl selenates and selenite-selenates. J. Solid State Chem. 2015, 229, 32-40. [CrossRef]

60. Chung, J.Y.; Jo, H.; Yeon, S.; Byun, H.R.; You, T.-S.; Jang, J.I.; Ok, K.M. Bi $i_{3}\left(\mathrm{SeO}_{3}\right)_{3}\left(\mathrm{Se}_{2} \mathrm{O}_{5}\right)$ F: A Polar Bismuth Selenite Fluoride with Polyhedra of Highly Distortive Lone Pair Cations and Strong Second-Harmonic Generation Response. Chem. Mater. 2020, 32, 7318-7326. [CrossRef]

61. Valkonen, J. Crystal structures, infrared-spectra, and thermal behavior of calcium hydrogenselenite monohydrate, $\mathrm{Ca}\left(\mathrm{HSeO}_{3}\right)_{2} \cdot \mathrm{H}_{2} \mathrm{O}$, and dicalcium diselenite bis(hydrogenselenite), $\mathrm{Ca}_{2}\left(\mathrm{HSeO}_{3}\right) 2\left(\mathrm{Se}_{2} \mathrm{O}_{5}\right)$. J. Solid State Chem. 1986, 65, 363-369. [CrossRef]

62. Frost, R.; Weier, M.; Bostrom, T.; Cejka, J.; Martens, W. Molecular structure of the uranyl mineral zippeite-An XRD, SEM and Raman spectroscopic study. Neues Jahrb. Mineral. Abh. 2005, 181, 271-279. [CrossRef] 